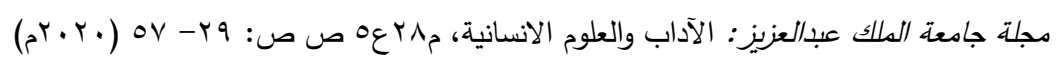

DOI:10.4197/Art.28-5.2

\title{
الأحكام والضوابط الفقهية المتعلقة بالنقود الرقمية الإكترونية (البتكوين أنموذجا)
}

\author{
د. يوسف بن هزاع بن مساعد الثريف

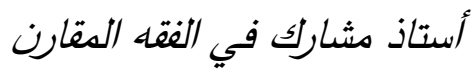 \\ جامعة الطائف، قسم الشريعة، كلية الثربعة والأنظمة
}

مستخلص. من النوازل الفقهية والقضايا المعاصرة في معاملات الناس مع التقدم التقني الذي غزا جميع مجالات الحياة الإنسانية ما عرف مؤخرا بالعملات الرقمية، وذلك بسبب تلك الطفرة الرقمية والتطور المذهل في المجال التقني، وأصبحت هذه العملات الرقمية تهدد العملات الورقية لأنها لا تحتاج إلى حمل كميات من هذه الأوراق، كما أنها تتسم بالعالمية فهي تغني عن الحاجة إلى استبدال العملات عند التنقل بين دول مختلفة. ومن أشهر وأبرز هذه العملات الرقمية ما يعرف بالبتكوين، وهي عملة رقمية أصبحت ذات شهرة وانتشار واسعين في مختلف أنحاء العالم، ولما لهذه العملات الآن من انتشار وتأثير على الاقتصاد العالمي إيجابا وسلبا، ولما

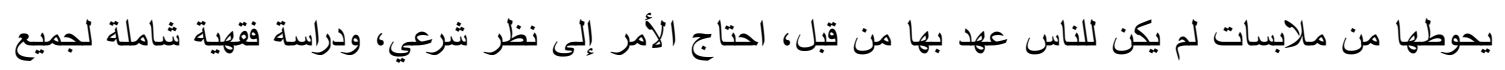
أحوالها وتداعياتها وآثارها، لهذا اخترت أن يكون موضوع بحثي هذا هو "الأحكام والضوابط الفقهية المتعلقة بالنقود

$$
\text { الرقمية الإكترونية" (البتكوين أنموذجا). }
$$

$$
\text { ورسوله وبعد. }
$$

\section{المقدمة}

إن الحمد الله نحمده ونستعينه ونستغفره، ونعوذ بالله فإن الناس لا يستغنون في معاشهم عن المعاملات

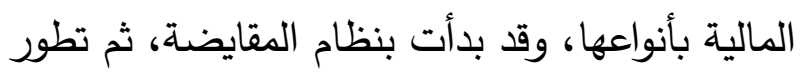

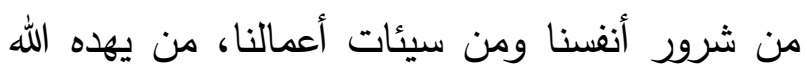

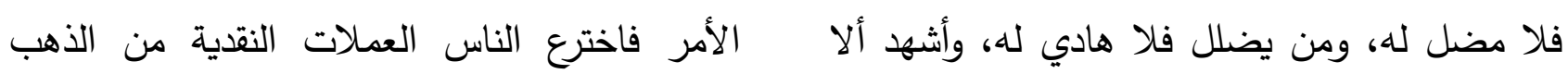

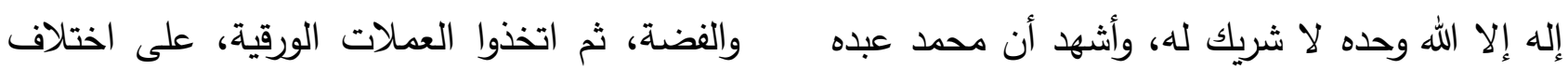


طريقة التعامل بها، والنظر في الأدلة الشرعية والفتاوى الفقهية والتأصيل الثرعي لهذه الأحكام ومعرفة الضوابط الفقهية الحاكمة للتعامل بها.

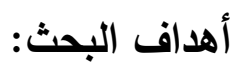
ويهدف البحث إلى ما يلي: ا-التعرف على العملات الرقمية وطرق التعامل بها. r-معرفة الأحكام الشرعية لهذه العملات. ب-معرفة الضوابط الشرعية للتعامل بهذه العملات.

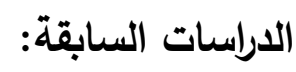
هناك بعض الدراسات العلمية الأكاديمية التي تتاولت

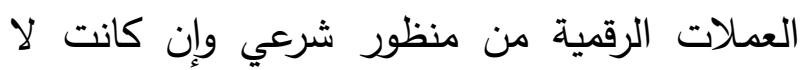
تزال قليلة نظرة لطرافة الموضوع، منها: - - النقود الإككترونية: مكمها الشرعي وآثارها

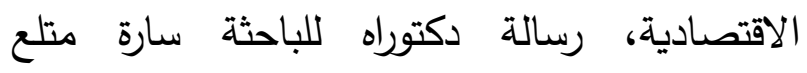

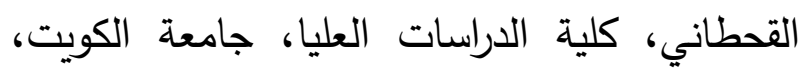
^ . . بام، تتاولت فيها الباحثة تعريف النقود والنقود الإلكترونية وتاريخها ونشأتها وأنواعها وكيفية عملها تُوليا

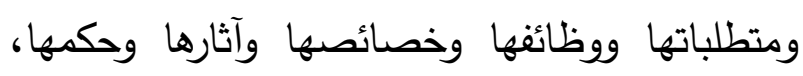
وانتهت الباحثة إلى صحة وصف العملات الرقمية

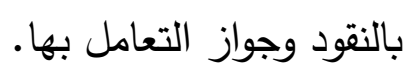

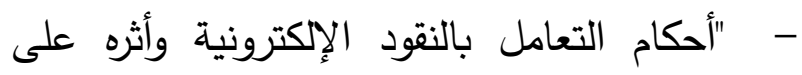
التعاملات المعاصرة" رسالة ماجستير للباحثة شيماء جودت مجدي عيادة منصور كلية الشريعة والقانون،

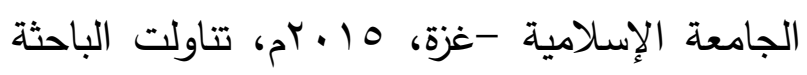

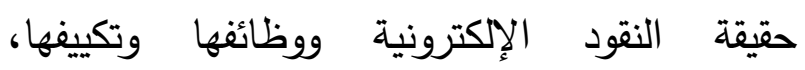
ومخاطرها وأثرها على السياسة النقدية وضوابط
أنواعها فحلت محل العملات النقدية، ثم ظهر ما يعرف بالمعاملات عن طريق الكروت الذكية المسماة الفيزا بديلا عن التعامل النقدي. وإن من النوازل الفقهية، والقضايا المعاصرة في لنعلي معاملات الناس مع التقدم التقني الذي غزا جميع مجالات الحياة الإنسانية ما عرف مؤخرا بالعملات الرقمية، وذلك بسبب تلك الطغرة الرقمية والتطور المذهل الذي وصلت إليه وأصبحت تهدد العملات الورقية لأنها لا تحتاج إلى حمل كميات من هذه الثه واهن

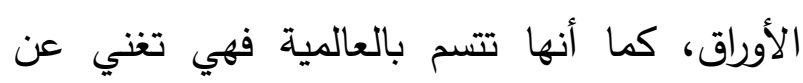
الحاجة الا استبدال العملات عند التنقل بين دول مختلفة. ومن أشهر وأبرز هذه العملات الرقمية ما يعرف بالبتكوين، وهي عملة رقمية أصبحت ذات شهرة وانتشار واسعين في مختلف أنجاء العالم، ولما لهذه

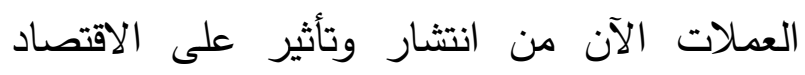

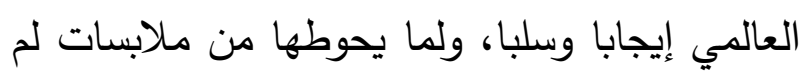

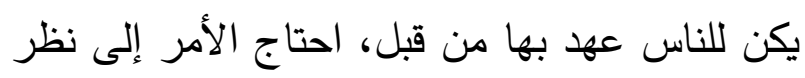

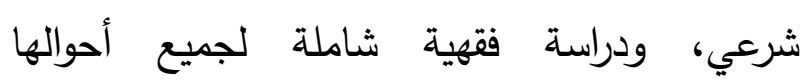
وتداعياتها وآثارها، لهذا اخترت أن يكون موضوع فئة بحثي هذا هو الأحكام والضوابط الفقهية المتعلقة بالنقود الرقمية الإككترونية (البتكوين أنموذجا). مثكلة البحث: بعود الرفئ تكمن مشكلة البحث في استخراج الأحكام الفقهية

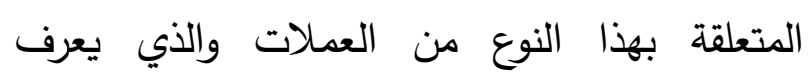
بالعملات الرقمية من خلال تحليل طبيعتها، وفهم 
من المراجع الفقهية والاقتصادية. r- مهدت للموضوع بتمهيد تاريخي لنشأة النقود والعملات وتطورها. r- عرفت المصطلحات الواردة في البحث بتعريفات الفقهاء والاقتصاديين ما أمكن ذلك. ع- عزوت الآيات إلى الدصحف الثريف بذكر التين اسم السورة ورقم الآية. ه- خرجت الأحاديث والآثار من مظانها في كتب

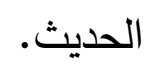

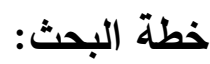
وتأتي خطة البحث على النحو التالي: تمهيد: نبذة عن نشأة النقود وتطورها. المبحث الأول: التعريف بالنقود الرقمية ونشأتها. المبحث الثاني: التكييف الفقهي للنقود الرقمية

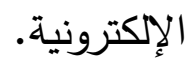

المبحث الثالث: الضوابط الشرعية للنقود الرقمية.

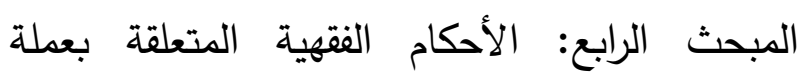
البتكوين، وفيه مطالب: المطلب الأول: تعريف عملة البتكوين. المطلب الثاني: التكييف الفقهي لعملة البتكوين. الدطلب الثالث: الحكم الثرعي لعملة البتكوين. الخاتمة وفيها أهم نتائج البحث وتوصياته. والله الموفق والهادي إلى سواء السبيل تمهيد: أولا: نثأة النقود وتطورها. إذا رجعنا بالتاريخ الى المجتمعات البدائية لوجدنا أن أنسان

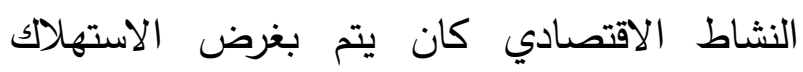

إصدارها، وأثر التعامل بها على بعض المعاملات المعاصرة، وانتهت إلى إباحة الثريعة الإنسلامية لها. - الأحكام الفقهية المتعلقة بالعملات الإكترونية (عملة بيتكوين نموذجا) - دراسة فقهية مقارنة، بحث الإنية

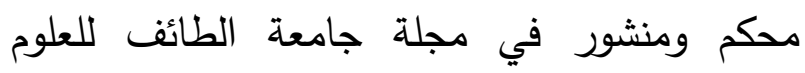

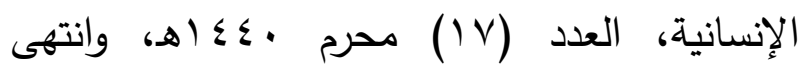
الباحث فيه إلى أن البيتكوين أموال مستقلة ولها مميزات ومخاطر وأنها يجري فيها الربا بعلة الثنية الثية الثيال وتجب الزكاة فيها، وأن التعدين فيها عمل مباح وهو عقد جعالة.

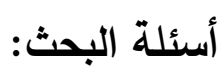
يطرح البحث عدة أسئلة منها: ما هو التكييف الثرعي للعملات الورقية التي ظهرت مؤخرا؟ وما حكم التعامل بها؟

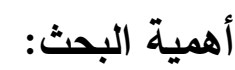
هذا البحث يتناول موضوعا من أخطر الموضوعات

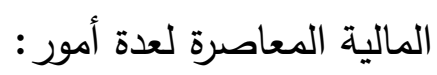
1- أن العملات الرقمية تعد نازلة من أهم النوازل الفقهية. r- أنها تمس جانبا حساسا من حياة الناس وهو

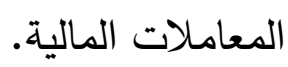
ب- أنها تعد من المسائل الغامضة التي تحتاج إلى الى نظر فقهي عميق لمعرفة تكييفها الشرعي ومن ثم الثماتي معرفة حكمها.

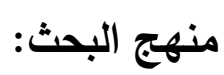
1- جمعت المادة العلمية المتعلقة بموضوع البحث 
ولأسرته نوعاً من الترف والعيش الكريم، فيصبح قادراً على إشباع متطلباتهم المادية، ويشترك جميع أفراد المجتمع في استخدامهم للنقود في حياتهم اليومية، فالكل يعمل من أجل الحصول على النقود، والكل يقبل في التنازل عن جزء منها في سبيل الحصول على ما يحتاجه من سلع وخدمات، ومع تطور

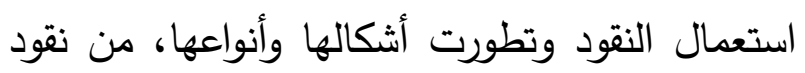
معدنية إلى نقود ورقية، ثم إلى نقود مصرفية، وأخيرا ما يعرف بالنقود الرقمية أو الإكترونية.

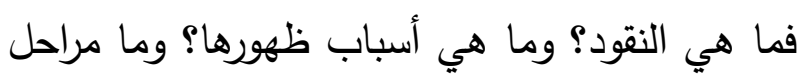
تطورها أنواعها؟ تعريف النقود:

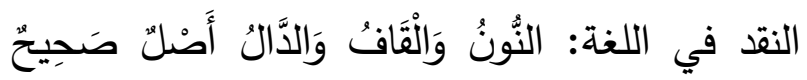

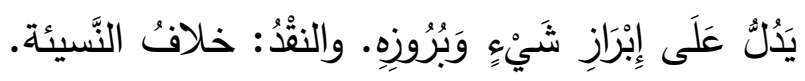

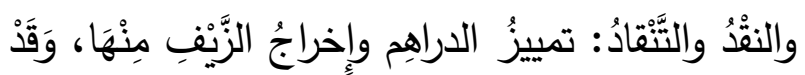

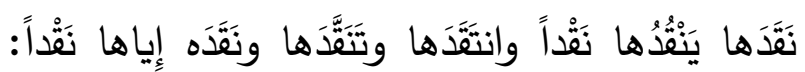

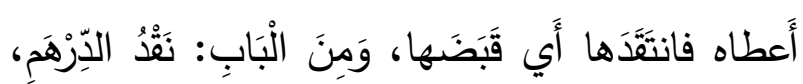

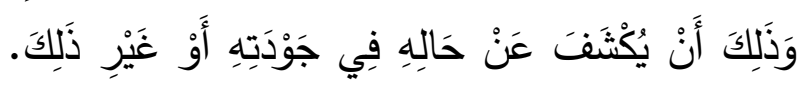

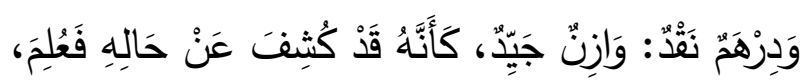

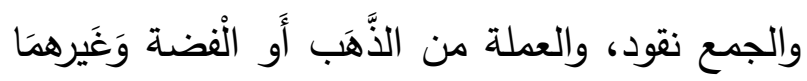

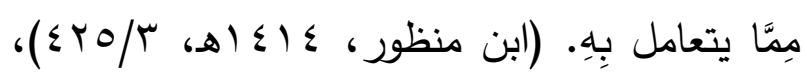

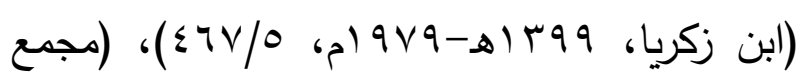

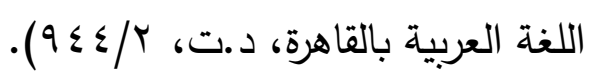

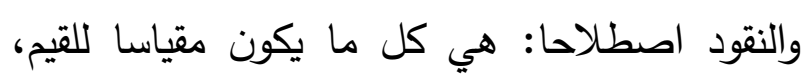

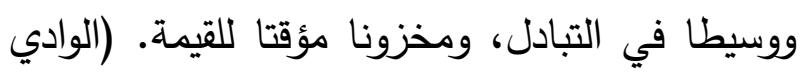

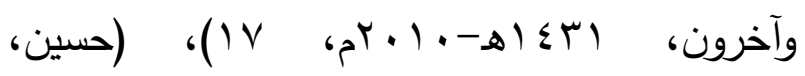

الذاتي، أو بمعنى آخر كانت فئات المجتمع سواء الفرد أو الأسرة أو القبيلة تقوم بالإنتاج ذاتيا، وفي

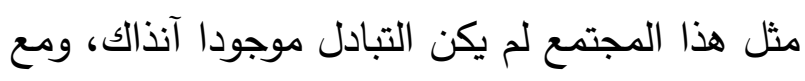

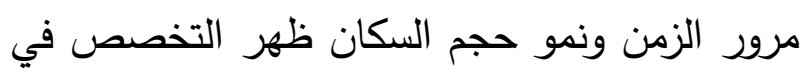

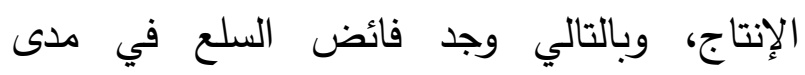
الوحدات التي تتجها، ومن ناحية أخرى وجدت ولتالت حاجات لهذه الوحدات تريد إثباعها، ومن ثمة نشأت التهات

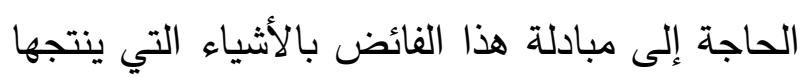
الآخرون التي تثيض بدورها عن حاجتهم الشخصية،

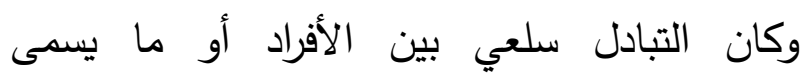

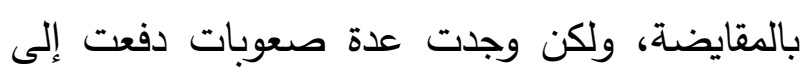

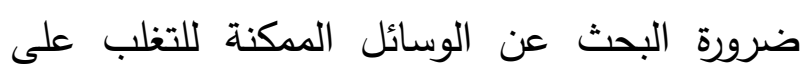

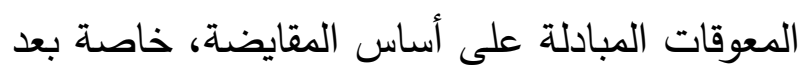

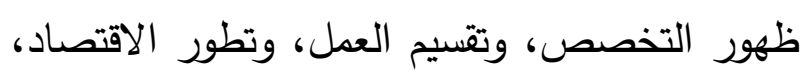

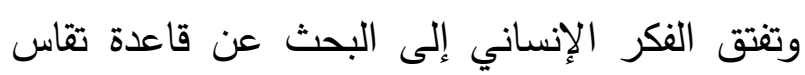
على أساسها قيم السلع المختلفة، وانتهى الأمر الإنى بوجود وسيلة للمبادلة لها قيمة ذاتية يقبلها الجميع في المعاملات يمكن تخزينها ونقلها من حيث الزمان والمكان والمتمثلة في النقود.

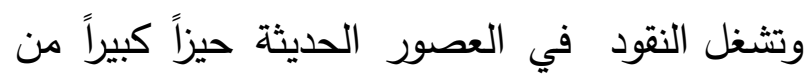
الفكر الاقتصادي والمحاسبي، فقد أصبحت أساس

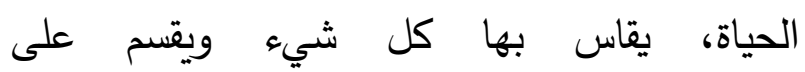
أساسها المجتمع، فالإنسان مدني بطبعاه، قليل بنفسه كثير بغيره، فكل محتاج إلى ما عند غيره، ومن طبيعة الإنسان أن يضن ببذل ما عنده إلا بعوض،

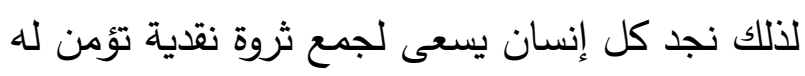


للأسعار، فكلما انخفض المستوى العام للأسعار، ارتفعت القيمة الحقيقية للنقود والعكس صحيح. ثانياً: أنها مقياس للقيمة: تمثل النقود أيضا وحدة لقياس القيم المالية، فتقوم وحدات النقود بقياس قيم السلع والخدمات المختلفة، ونسبة قيمة كل سلعة أو وحئ

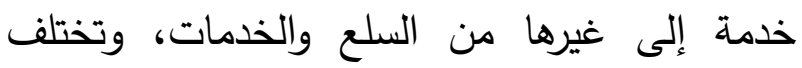
النقود كوحدةً للقياس عن المتر والكيلوجرام والطن وغيرها من وحدات القياس الأخرى في أنها ليست

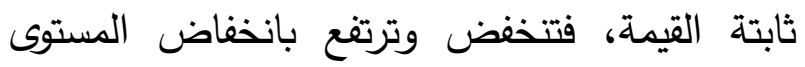

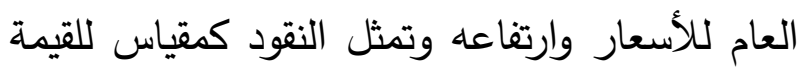

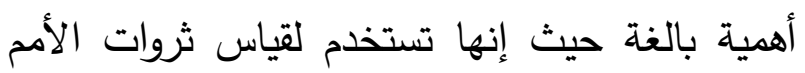
وموازنات الدول وأصول الثركات وخصومها، وغيرها من الاستخدامات الأخرى الأساسية لقيام اقتصاد

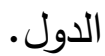
ثالثاً: أنها مستودع للقيمة : تتميز النقود عن غيرها من وسائل حفظ الثروات التي لا تتأثر بمرور الوقت

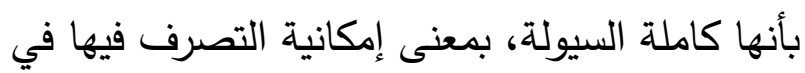
أي وقت كان، لشراء أي شيء من الأسواق أو

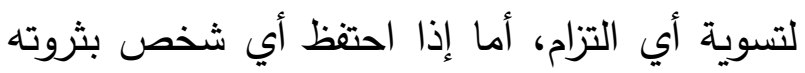

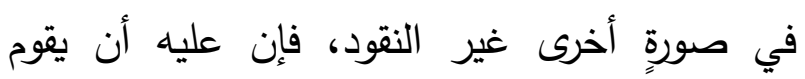

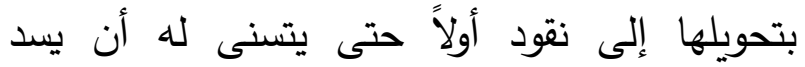
حاجاته التي يرغبها. رابعاً: أنها معيار للدفع المؤجل: تستخدم النقود أيضا كمقياس للقيم المستقبلية، فتقوم النقود بقياس الديون

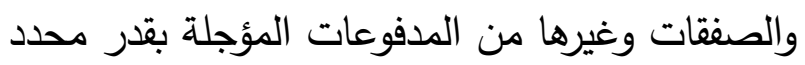
من الوحدات النقدية، فإذا تعاقد شخص ما مات مع آخر

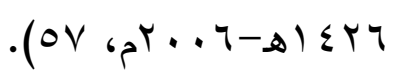

والنقود هي الثيء الذي يلقي قبولا عاما في التداول،

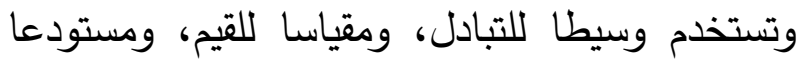
لها، كما تستخدم وسيلة للمدفوعات الآجلة، واحتياطيا لقروض البنك، ولذلك فإن التعريف الموجز للنقود وهو أن (النقود هو كل ما تفعله النقود) إذا صح فإنه أي شيء يقوم بوظيفة النقود يكون بالفعل نقودا. أسباب ظهور النقود: ظهرت النقود للأسباب الاتية: 1- استجابة لحاجات الناس. r- التطور الاقتصادي والاجتماعي. r- القضاء على صعوبات الدقايضة (تبادل سلعة بسلعة أخرى). ؟- لتسهيل عمليات التبادل التي ازداد حجمها

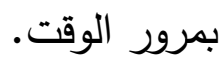
وظائف النقود وأهميتها: تقوم النقود بعدة وظائف بالغة الأهمية لا غنى للنشاط الإنساني عنها، من هذه الوظائف:

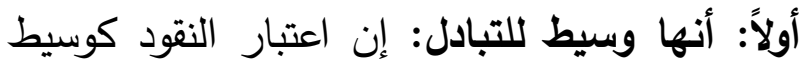
للتبادل، يعنى قبول المتعاملين لها في السوق وقيمة الوحدة من النقود، لا يقصد بها قيمتها النقدية، حيث إنها ثابتة لا تتغير، بل تمثل قيمة النقود الحقيقية التي تعكس القوة الشرائية لها. والقوة الثرائية للنقود هي عبارة عن كمية السلع والخدمات التي يمكن أن تتم بها عملية التبادل في السوق بواسطة وحدة نقدية وترتبط النقود ارتباطاً عكسياً مع المستوى العام لمان 
التي قام بها بنك استكهولم بالسويد سنة (707 (م)،

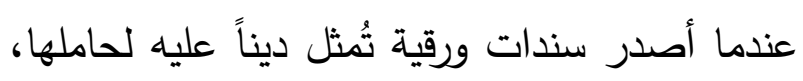

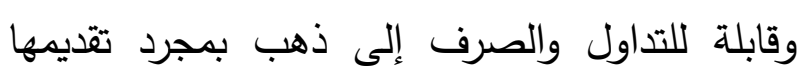
للبنك، وقد ظهرت أول أشكال النقود الورقية في صورة هذه الإيصالات النمطية التي تحولت فيما بعد التحال إلى سندات لحاملها، وأصبحت تتداول من يد إلى يد الإندال دون الحاجة إلى تظهير، حيث إن هذه السندات

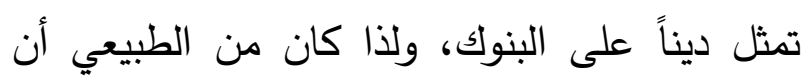

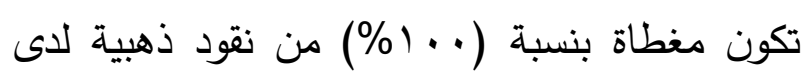

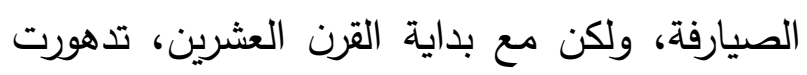

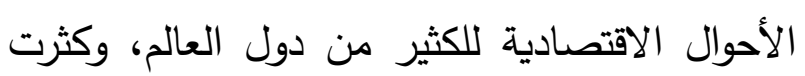
الحروب ونقص غطاء الذهب، مما اضطر السلطات النقدية لوقف استعدادها لصرف القيمة الاسمية للنقود الورقية بما يعادلها من ذهب.

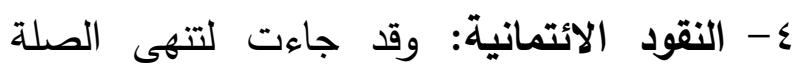
نهائياً بين النقود والمعادن النفيسة، وأعطى انقطاع الأنها:

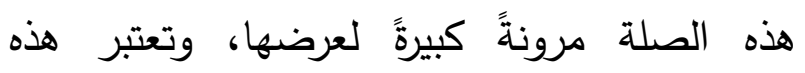

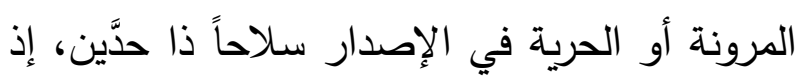

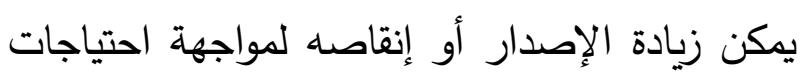
التبادل التجاري، غير أن التمادي في الإصدار تئدي الإدي

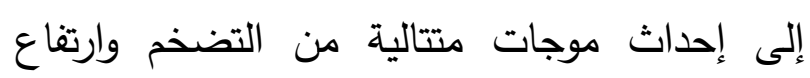

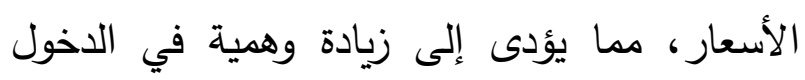
النقدية للأفراد. لذلك يتطلب إصدار النقود الائمانية

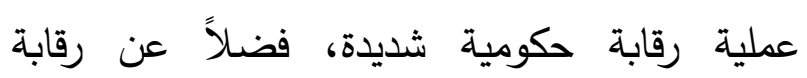
المؤسسات النقدية . وتتقسم النقود الائمانية إلى نقود قانونية ونقود
على توريد كمية معينة من السلع في مقابل مبلغ

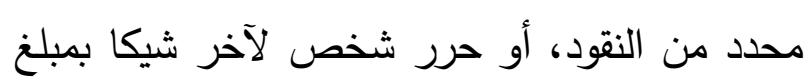

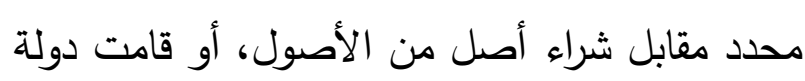
بإصدار سندات حكومية بقيمة اسمية محددة مقابل الحصول على مبلغ محدد يمثل القيمة الحالية للسند،

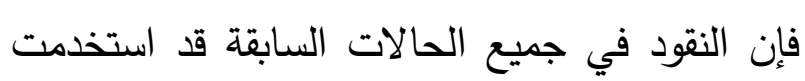
لقياس المدفوعات المؤجلة. مراحل تطور النقود: أخذت النقود أشكالا مختلفة وتطورت في أنواء عدور عدة عبر التاريخ البشري، وفيما يلي نستعرض مراحل تطور النقود وأنواعها:

1- النقود السلعية: ظهر أول شكل من أشكال النقود في شكل سلع مقبولة تعارف الإنسان على الى إنى استخدامها كوسيط في عملية التبادل، ولقد استخدم الإنسان أنواعاً لا حصر لها من السلع كوسيط للقيمة

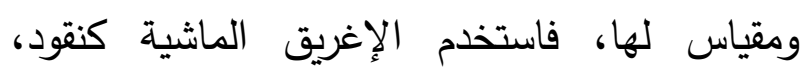
وتعارف أهل سيلان على استخدام الأفيال كنقود، واستخدم الهنود الحمر التبخ، بينما كانت نقود أهل الهل الهان الصين هي السكاكين. r- النقود المعدنية: مع ازدياد حجم الصفينات

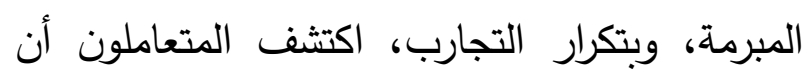
المعادن هي أفضل وسيط لإجراء عملية التبادل بينهم من حيث كونها أقوى على البقاء، كما يمكن تجزئتها وتشكيلها بالحجم والشكل المطلوبين.

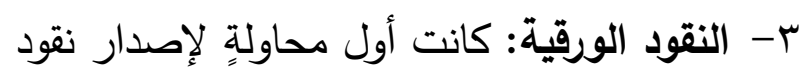
ورقيةٍة في شكلها الحديث المعروف لدينا، هي تلك الك الك 
المبحث الأول: التعريف بالنقود الرقمية ونشأتها:

أولا: تعريف النقود الإكترونية:

تعرف النقود الرقمية أو الإكترونية بتعريفات عدة

منها:

- "مجموعة من البروتوكولات والتوقيعات الرقمية

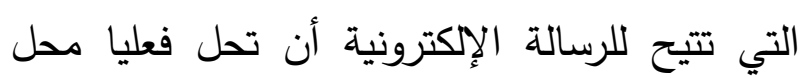

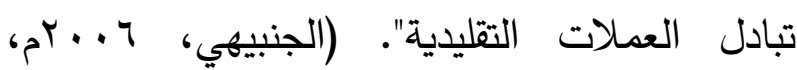

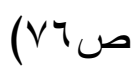

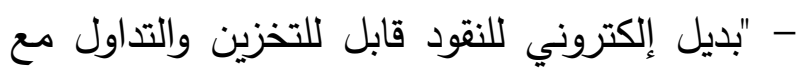
عدم قابلية تزييفه، فهي عبارة عن أرقام يتم نقلها من

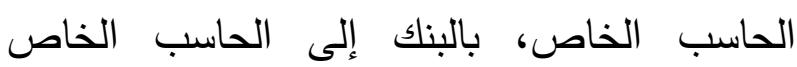
بالمشتري، ومنه إلى الحاسب الخاص بالبائع، عن بالبن طريق القرص الصلب المثبت على الحاسب".

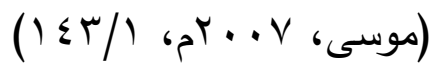

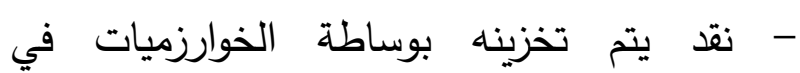

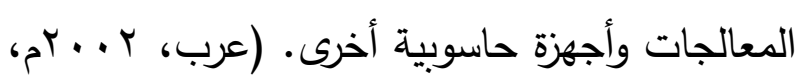

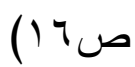

وتعرف بحسب البنك المركزي الأوربي بأنها: "مخزون إلكتروني لقيمة نقدية على وسيلة إلكترونية مثل بطاقة بلاستيكية قد تستخدم في السحب النقدي

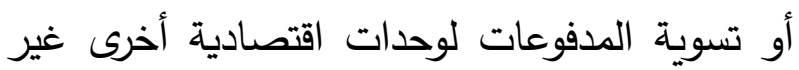
تلك التي أصدرت البطاقة دون الحاجة إلى وجود حساب بنكي عند إجراء الصفقات وتستخدم كأداة

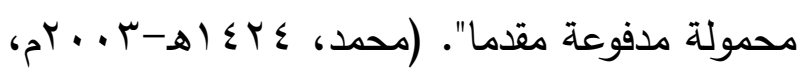

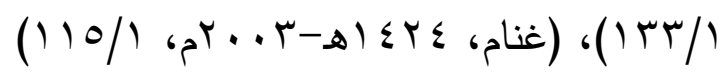
ويلاحظ على هذه التعريفات أنها تتفق على كون
الودائع: - (ائم

أ. النقود القانونية: وهي النقود الأساسية المعاصرة، وسميت "بالنقود القانونية" لأنها تستمد

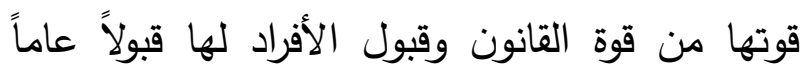
ونظراً لاحتكار البنك المركزي حق إصدارها، وتمثل

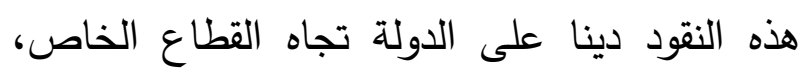
ويتحتم على البنك المركزي الاحتفاظ بأصول مساوية في قيمتها لقيمة ما أصدره من نقود، وتسمى هذكي الصني الأصول بالغطاء النقدي. (المغربي، محمد الفاتح،

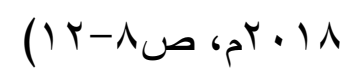
ب. نقود الودائع: أو النقود الكتابية، وتعتبر أهم أنواع النقود لأنها تمثل وسيلة هامة للدفع كما تشكل نسبة مرتفعة من إجمالي النقود المتداولة في الدول ذات الأنظمة المصرفية الحديثة، وتتثكل هذه النقان النقود

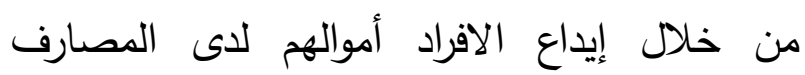

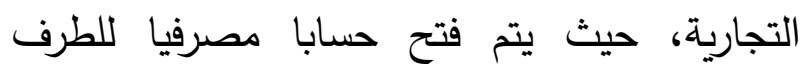
المودع يقوم بالسحب من حسابه للوفاء بالتزاماته،

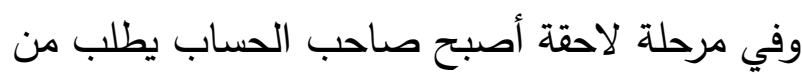
المصرف تحويل مبلغ من النقود من حسابه الى هرحيه لاحئ

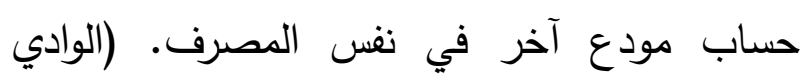

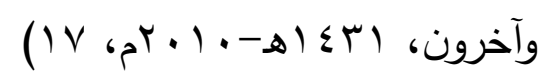

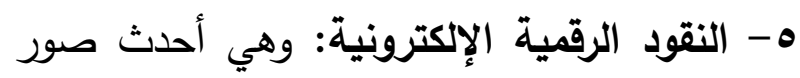
النقود التي ظهرت مؤخرا وأخذت في الانتشار والتداول، والتي سنتكلم عنها وعن أحكامها الشرعية

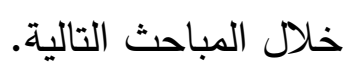


العملات الرقمية قيما نقدية يتم تخزينها وتداولها وكذلك الآلات التي تقوم بإصدارها. (محمد،

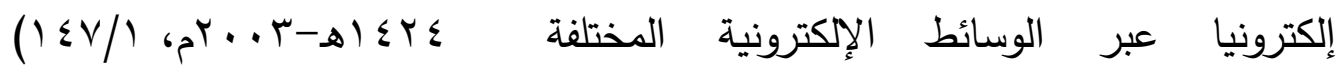
كالحاسوب وأجهزة الجوالات الذكية والبطاقات وإذا كان التشفير بمعناه العام يهدف إلى إيجاد وسيلة

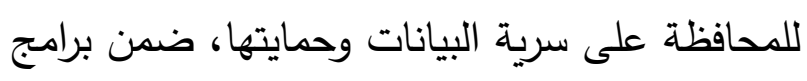
تحول وتترجم المعلومات إلى أرقام ورموز وحروف لهن

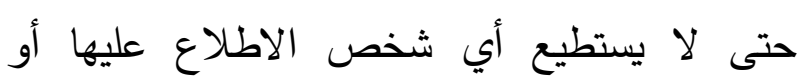

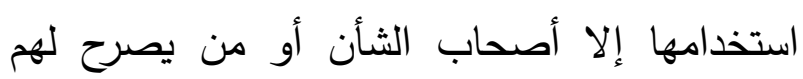
قانونا بذلك فإن النقد الإكتروني يستخدم التشفير وسيلة لإتمام التعاقد الإلكتروني حتى لا يستطيع أي لإني

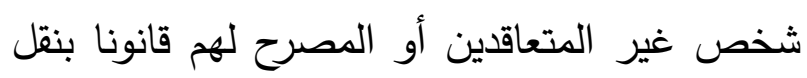
أو تلقي النقد الإلكتروني المخزن بطريقة تشفيرية تضمن حماية سرية بيانات كل المتعاقدين. (الرومي،

$$
\text { (r) }
$$

المبحث الثاني: التكييف الفقهي للنقود الرقمية الإلكترونية. عند النظر في النقود الرقمية بشكل خاص، نجد خلافا عميقا بين الاقتصاديين في تكييفها، وهو الأمر

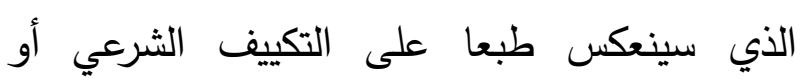
الفقهي لها، ومن ثم نجد أن تكييف النقود الرقمية قد يتعدد إلى صور شتى بحسب وظائفها المتعددة. وترجع أسباب الخلاف في التكييف الشرعي للعملات الرقمية أو الإلكترونية إلى الأسباب التالية:

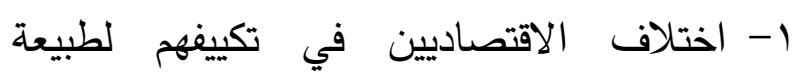
العملات الإلكترونية.

r- النظرة الإسلامية التي تعتبر جميع الإلقوديه.

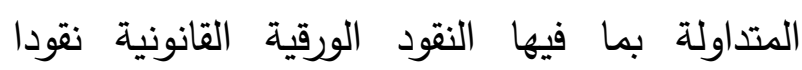

\section{ثانيا: نثأة النقود الإكترونية:} نشأت العملات الرقمية أو النقود الإكترونية كنتيجة طبيعية للتطور التكنولوجي في مجال الإنترنت ونظم المعلومات، واستجابة لتلك الطفرة الهائلة في مجال الإنترني التسوق الإكتروني التي أخذت في الاتساع في السنوات الأخيرة، حيث استلزم هذا النمط من التجارة

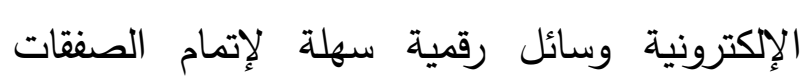

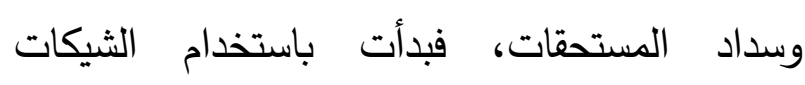
والتحويلات والبطاقات البنكية، ولكن ظهرت لهات لهات عيوب ومعوقات، مما استدعى البحث عن وسائل أكثر سهولة للتداول، وأسرع نقلا للأموال. وتعتبر البداية الحقيقية لهذه العملات الرقمية عام

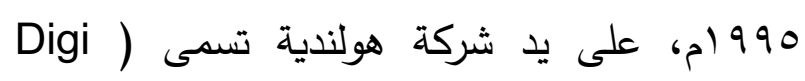

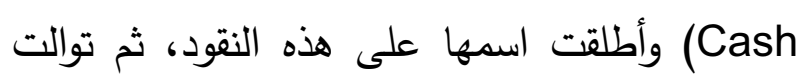
بعد ذلك العملات الرقمية بأسمائها المختلفة.

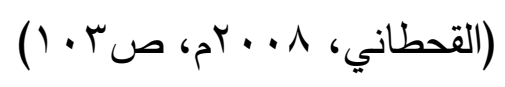

كما عرفت اليابان النقود الإلكترونية وناقشتها بشكل رسمي عندما تشكل مجلس يضم مجموعة من

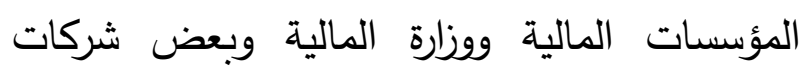
الاتصالات والتلغراف، وتم في هذا الاجتماع مناقثة

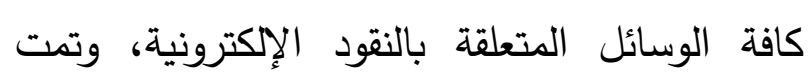
الموافقة على إصدار بعض صور النقود الإلكترونية، الإكتهونية 
الوحدات عند فقد البطاقة أو تلفها.

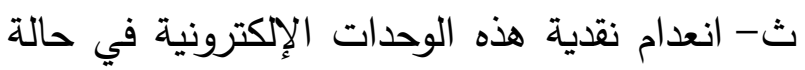
عدم التزام جهة الإصدار بتحويلها إلى قيمة نقدية، لإمكانية إصدارها من غير البنوك المركزية.

موانع هذا التكييف:

يرى بعض الباحثين عدم صحة هذا التكييف الفقهي للنقود الإلكترونية من عدة أوجه:

الأول: لو كانت هذه الوحدات سندات دين على من عندة الإهن: أصدرها لما ضاع الحق الذي هي سند به بتلفها أو لأوحلت بضياعها، لأن الدين لا يتلف بتلف وثيقته، بينما

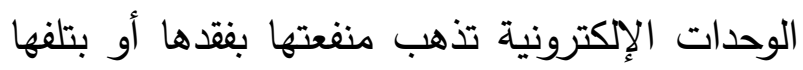
ولو كان حاملها يملك بينة على أنه كان يحمل وحدة لإنها إلكترونية قيمتها كذا فضاعت أو تلفت، بينما وثيقة بلة بئه الدين إذا تلفت أو ضاعت لا يترتب على ذلك ضياع الحق بالكلية، بل يتحرى القاضي في البينة، مما يدل على أن الوحدات الإككترونية ليست سندا للدين.

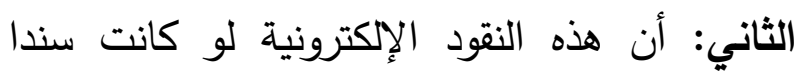

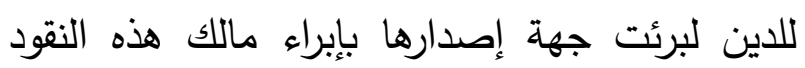

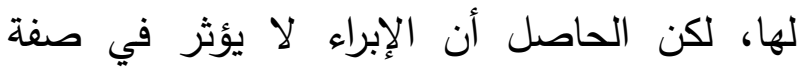
الوحدة الإلكترونية النقدية، فهي بذلك ليست سندا.

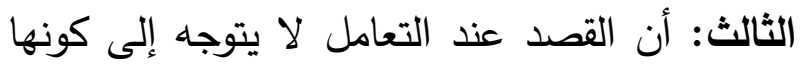
سندا بل قد لا يخطر على بال من تعامل بها، وإنما القصد إلى أنها تحقق لمن حازها منافع معتبرة ككونها وسيلة للتبادل ومقياسا للقيمة، وكما هو مقرر

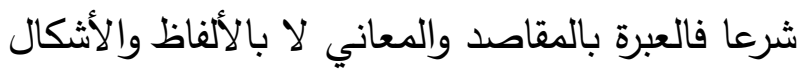

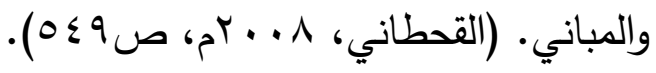

ائتمانية لارتباطها بالنقدين (الذهب والفضة) أو غيرهما من السلع المهمة. r- الخلط بين النقود الإلكترونية وغيرها من الوسائل

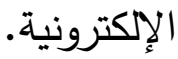
ع- اعتبار ما تستند عليه العملات الرقمية من نقود ورقية في حوزة جهة الإصدار • (منصور، با؟ أهـ (EV ص 10 ويمكن إجمال الآراء حول التكييف الفقهي للنقود الرقمية باعتبارها قيمة مخزنة على وسيط إلكتروني فيما يلي: 1 - تكييفها كسند قرض أو سند دين: وذلك من باب إطلاق العام على الخاص، وذلك أن النقود الرقمية لما كانت عبارة عن وحدات إلكترونية تشجن على وسيط إلكتروني ولها شفرة خاصة بها، تعطى مقابل القيمة النقدية المدفوعة سابقا، بحيث تلتزم جهة إصدارها بتحويل هذه الوحدات الإكترونية إلى نقود عادية متى طلب صاحبها ذلك، فإن هذه الوحدات لا تعدو أن تكون سند قرض، أو سند دين على الجهة المصدرة لها، وهذا التكييف يقوم على لعى لرصن أساس عدم نقديتها. واستدل أصحاب هذا التكييف على هذه الصورة بما يلي: أ- وجود الدفع المسبق من العميل لجهة الإصدار. ب- ضمان جهة الإصدار للقيمة النقدية العادية عند طلبها من العميل فهي بذلك دين حال. ت-ضمان جهة الإصدار للقيمة النقدية لهذه لهن لهن 
النقدين (الذهب والفضة) هي غلبة الثمنية أي كونهما جنس الأثمان في الغالب، وهي بذلك علة قاصرة كما هو مذهب المالكية (الخرشي، د.ت،

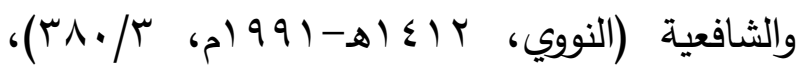
وذلك ليس محل اتفاق بين الفقهاء، فقد ذهب بعض الفقهاء إلى أن العلة فيهما هي مطلق الثمنية، فكل ما كان ثمنا يجري فيه الربا، وهو قول بعض السلف كيحيى بن سعيد وربيعة الرأي والليث بن سعد

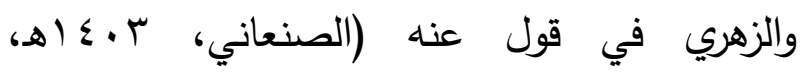

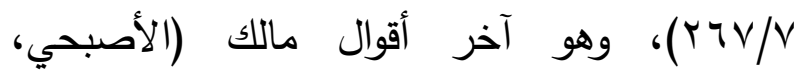
10 (هـ 10 محمد بن الحسن الشيباني من الحنفية (الكاساني، 7 7 ( اهـ-919 (م، 9/70/7)، وهو قول عند الحنابلة

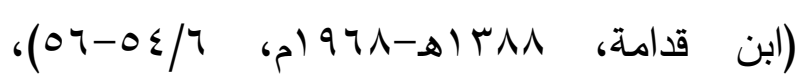

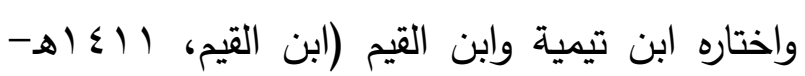

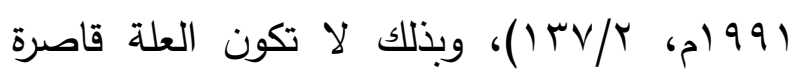

عليهما.

وهذه الوحدات الإلكترونية تدفع كثمن فتتوافر فيها الثمنية، ويتحقق فيها الرواج وهي تشبه الذهب والفضة والأوراق النقدية في انتشارها وبذلك يقع فيها الربا بعلة الثمنية، فيشترط في بيعها بجنسها التماثل والتقابض، ولكن التقابض فيها حكمي لأنها ليس لها وجود حسي فهي مجرد شفرات. (العقيل، د.ت،

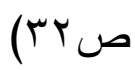
الثاني: انفكالك الجهة بين القيمة الذاتية للوحدات الإكترونية وبين القيمة التي تروج بها باعتبار r- تكييفها كعرض تجاري:

حيث إن الوحدات الإلكترونية هي مال منقول تتوجه له الرغبات، ويعرض للبيع والشراء، وله قيمة ذاتية باعتبار جنسه. واستدل أصحاب هذا الاتجاه بعدة أمور: أ- أن الوحدات الإلكترونية مال متقوم مرغوب فيه يباع ويشترى، والعقد بين العميل وجهة الإصدار، وكذلك بين العميل والتاجر واقع عليها، إذ هي المقصود لفظا ومعنى وهذا شأن العروض التجارية.

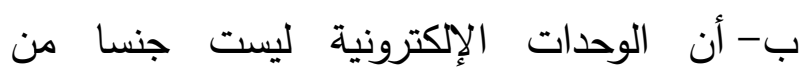
الأجناس الربوية الستة المنصوص عليها في حديث عبادة بن الصامت أنه قال: "إنِّي سَمِعْتُ رَسُولَ اللهِ

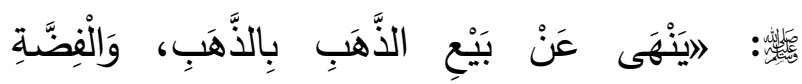

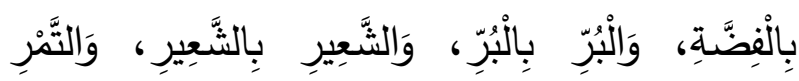

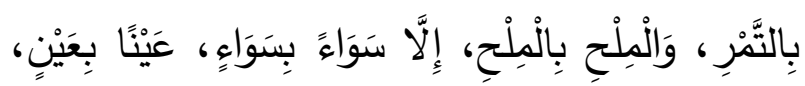

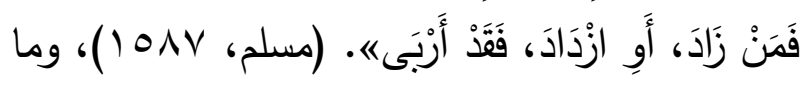
كتب بالتشفير عليها من تقدير قيمتها وتعيين اسمها يعد أمرا اصطلاحيا مجازيا لا تخرج بها من حقيقته في أنها مال متقوم ليس من جنس الأموال الربوية، كما أنها تخالف النقود الورقية من حيث طبيعتها وذاتها من جهة، ومن حيث العلة الربوية من جهة

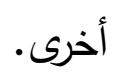
موانع هذا التكييف: منع بعض الباحثين من هذا التكييف للنقود الإلكترونية من عدة وجوه: الأول: أن هذا التكييف مبني على أن علة الربا في 


\section{موانع هذا التكييف:}

بالنظر في هذا التكييف يمكن الطعن فيه من

وجهين:

الأول: أن التعادل في هذه الوحدات الإلكترونية بين

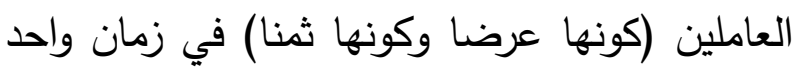

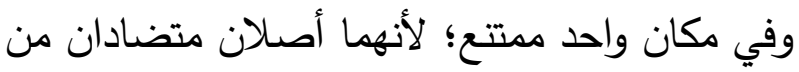
حيث الغرض والاستخدام، والمتضادان لا يجتمعان. الثاني: أن هناك فروقا بين الوحدات الإكترونية والفلوس كما يلي: أولا: أن استخدام النقود الإلكترونية لا يقتصر على

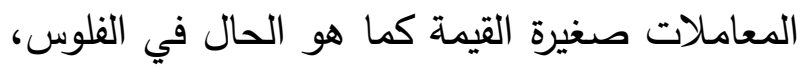
والسلع التي تستخدم في مقابلها لا تعد من محقرات

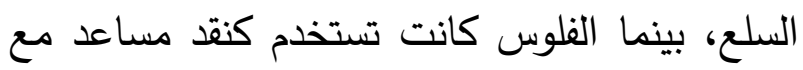
الذهب والفضة لشراء المحقرات من السلع، وفي لئي المعاملات صغيرة القيمة.

ثانيا: في انتقال الوحدات الإلكترونية من أصلها العرضي إلى الثنية قوة أفقدتها القدرة على رجوعها إلى أصلها في حال إبطالها، بخلاف الفلوس فإنها إذا كسدت وبطل التعامل بها فلها قيمة بنفسها كسائر

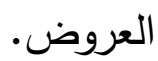

ثالثا: أن قيمة الوحدات النقدية مرتبطة من حيث الذات والنشأة بقيمة العملات النقدية، وهي بذلك هلك موغلة في الثمنية، بخلاف الفلوس فإنها مختلف في وني

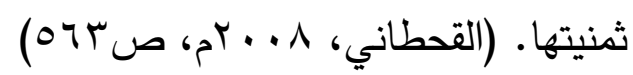
ع - تكييفها كعقد صرف: والصرف: هو "هو بيع نقد بنقد سواء اتحد الجنس أو هوبي
الاستعمال، فيلزم عنه انفكاك الجهة في الحكم عليهما. الثالث: أن لهذه الوحدات الإلكترونية خصائص النقد

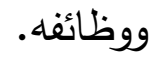
الرابع: أنه ليس كل مال مدخر مرغوب فيه بذاته تجري عليه أحكام عروض التجارة. (القحطاني،

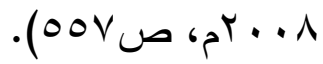
r- تكييفها كفلوس: "والفلوس هي نوع من النقود المضروبة من غير الذهب والفضة قيمتها سدس درهم" (قلعجي وقنيبي،

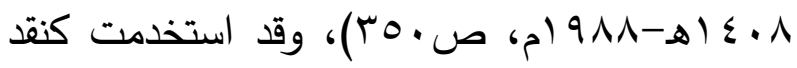
مساعد احتاج الناس إليها لتفي بالمعاملات المالية

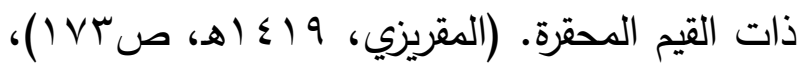
ووجه تكييف الوحدات الإلكترونية بها من حيث إن هذه الوحدات الإككترونية يتجاذبها عاملان؛ عامل أصلها وهو كونها عرضا، وعامل واقعها بعد الرواج

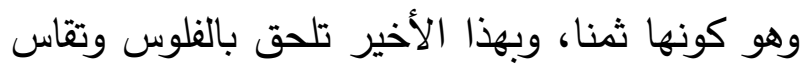
عليها. واستدل من كيفها كذلك بأمور :

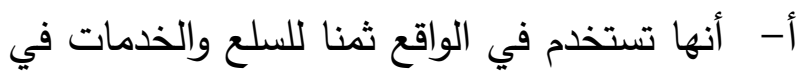
المعاملات محدودة القيمة، فيثبت لها وصف الثنية لهات لهات بالاصطلاح المشروط بالعقد.

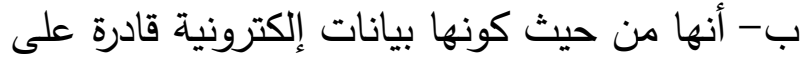
الانتقال لاستخدامها في منافع معينة بقيمة معينة، بحيث تخضع لعامل العرض والطلب في البيع.

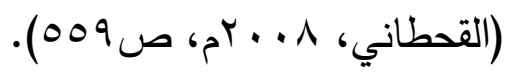


اختلف، وسواء كان النقد من الذهب أو الفضة أو أساس أنها بدل عن النقود الورقية.

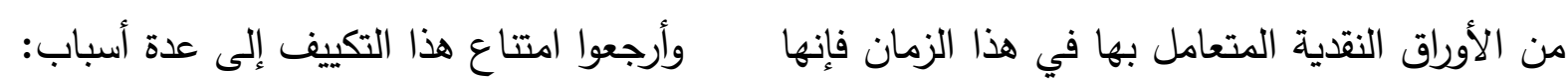

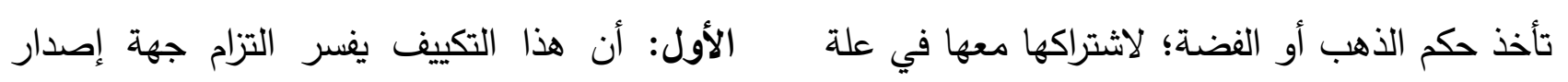

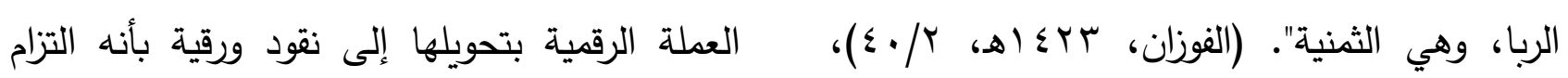

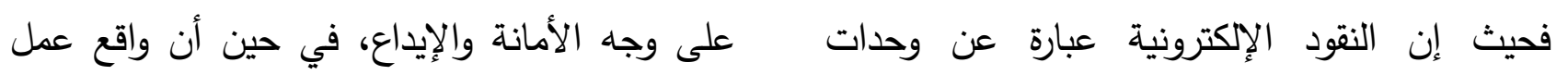

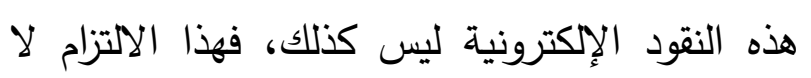
يعني أنها تحتفظ بالمدفوع قبل النقود الإككترونية كودائع بحيث لا يحق لها التصرف فيه، كما لا يلزم منه أنها تسحب المدفوع قبلها عن التداول كغطاء إلزامي لهذه الوحدات الإلكترونية، بل إن تلك القيمة

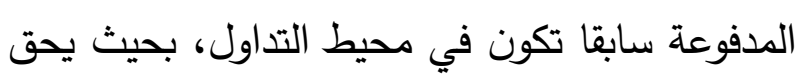

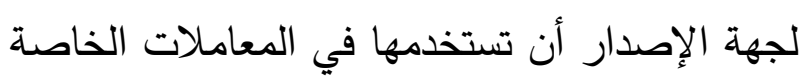

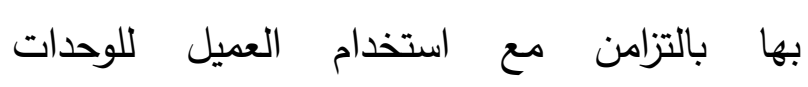

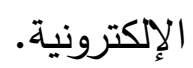

الثاني: أن هذا التكييف يفترض انتفاء القيمة الذاتية للوحدات الإكترونية، وذلك غير حقيقي من وجهين:

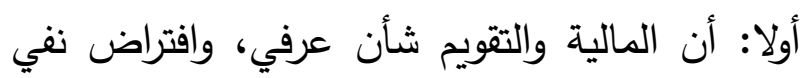

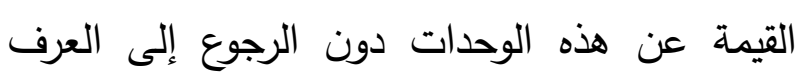

غير صحيح.

ثانيا: أن لهذه الوحدات الإلكترونية قيمة ذاتية منذ

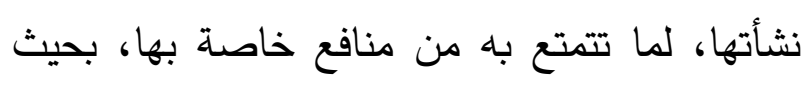
تتوجه لها الرغبات ابتداء وتكون محلا للبيع والثراء.

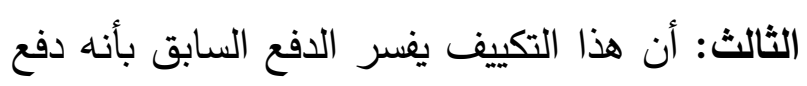

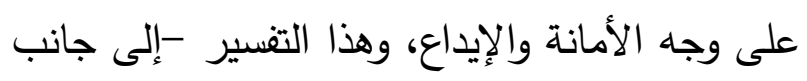
سقوطه بسقوط افتراض انتفاء القيمة الذاتية للوحدة ولها الإلكترونية، وسقوط تفسير التزام جهة الإصدار إلكترونية تشحن على وسيط إلكتروني ولها رقم مشفر خاص بها، تعطى مقابل القيمة النقدية

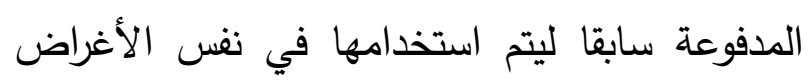
التي تستخدم فيها النقود الرقمية، وتلتزم جهة إصدار

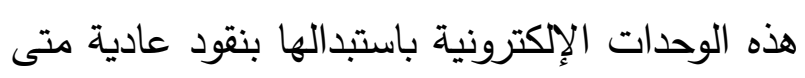

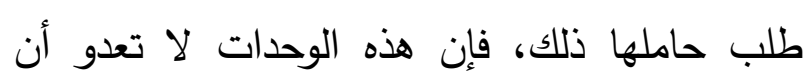

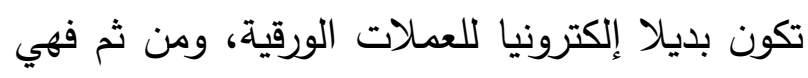
عبارة عن بدل لقيمتها من العملة النقدية، وللبدل

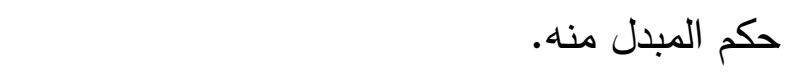
وقد استدل أصحاب هذا الاتجاه في تكييفها بما يلي: أ- أن النقود الإلكترونية تحمل قيما مالية وقوة شرائية مساوية للورقة النقدية وتستخدم كوسيلة للدفع والتبادل. ب-أن هذه الوحدات الإككترونية لها قدرة على التجزئة والتبادل. ج- أن هذه الوحدات الإكترونية لها قدرة على الدوران ولو بشكل محدود. موانع هذا التكييف: وقد وجهت سهام النقد إلى هذا التكييف رغم واقعيته

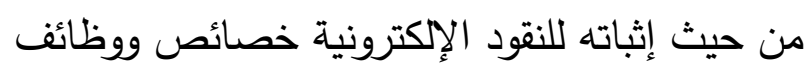

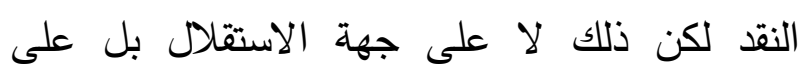


واستخدامها أثمانا بين الأطراف المختلفة، وقدرتها على التحول إلى النقود العادية أو المكتوبة بالتزام جهة إصدارها بذلك، ومن ثم فهي تعد نقودا مستقلة بذاتها لها طبيعتها الخاصة. واستدل أصحاب هذا التكييف الفقهي للوحدات

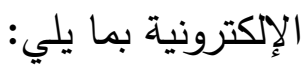
1- تعارف الناس على استخدامها كوسيط للتبادل ووحدة للحساب، ومقياس للقيمة. r- قدرة هذه النقود على التداول من طرف ومعياسئل آخر من خلال إعادة عمليات التشفير ذاتيا باستخدام برنامج النقود الإلكترونية، دون الحاجة إلى عملية بنكية لإتمام التعاقد بين حامل الوحدات الإككترونية

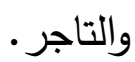

r- عمليات الإصدار والتدمير للنقود الإلكترونية تسجل خارج ميزانية جهة الإصدار. (القحطاني،

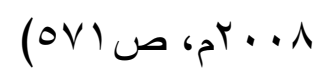

وعند التأمل لحال النقود الإكترونية نجد أن هذا التكييف الأخير هو الأليق بها والأنسب لها، والأقرب لواقعها، وطريقة عملها، لكن ينقصها التتظيم والتقنين على المستوى العالمي، وأن تحظى بالقبول العام، فلا

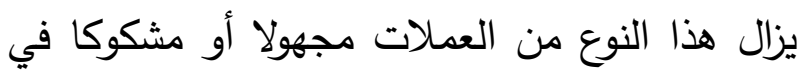
قانونيته وضمانته لاى كثير من الناس، ولا يزال انتشارها محدودا في كثير من مناطق العالم، فإذا تم

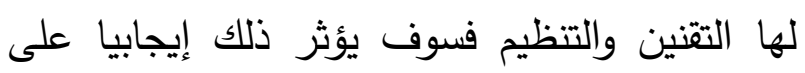

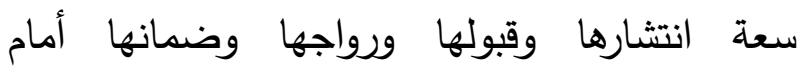
منصات القضاء عند التتازع بشأنها.
بتحويلها إلى نقود على سبيل الأمانة والإيداع- فإنه يسقط أيضا بمعروفة الفروق بين حساب الوديعة بالمعنى الفقهي، وبين حساب النقود الإكترونية والتي لبني تتمثل فيما يلي: أولا: في حساب الوديعة يكون موضوع العقد حفظ

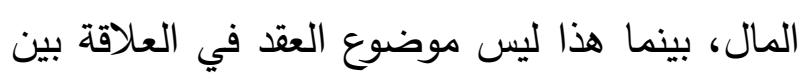
العميل وجهة الإصدار. ثانيا: في حساب الوديعة لا يحق للمودع لديه

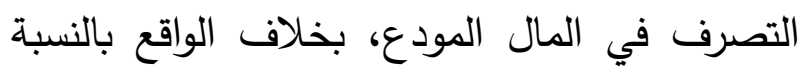
للنقود الإكترونية. ثالثا: في حساب الوديعة تنتهي العلاقة بين المودِع والمودع لديه بمجرد نقل الوديعة إلى الغير، وهذا غير واقع بالنسبة للعلاقة بين العميل وجهة إصدار

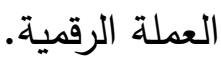
رابعا: في حساب الوديعة لا يضمن المودع لديه

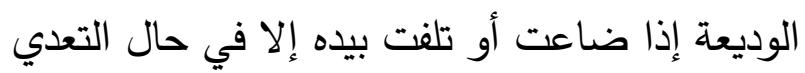
أو التفريط، وهو بخلاف ذلك في العقد الذي بين

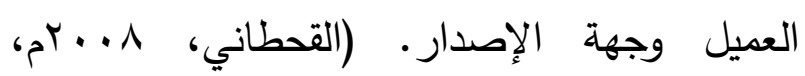
ص 07V-070) 0- تكييفها كنقود مستقلة: فهذه الوحدات الإلكترونية لما كانت تستوفي وظائف هولفي النقد وتحمل خصائصد، فإنها تعد نقودا مستقلة بذاتها، وهي تمثل بداية مرحلة جديدة في سلسلة

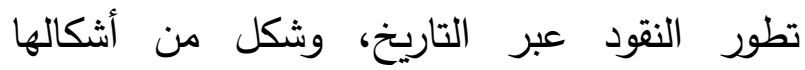
الخاصة، لما تتميز به من طبيعة خاصة في طريقة

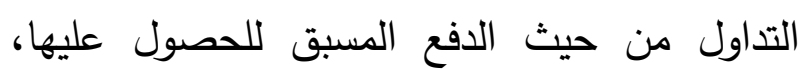


النقدية والتوازن بين المعروض النقدي والسلعي وانتهاء باتخاذ الإجراءات اللازمة لمواجهة المشكلات التي قد تواجهها، من أجل حفظ الحقوق وفض إل اء المنازعات.

r - توافر الضوابط الأمنية النلازمة:

وذلك بتحديد كل ما من شأنه أن يحفظ الاستقرار النقدي للعملات الإككترونية، من تحديد الحد الأدنى من المواصفات الأمنية لها حتى يسمح لجهات الإصدار بإصدارها، وإلزام جهات الإصدار أيضا

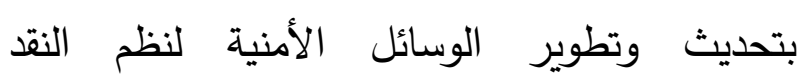

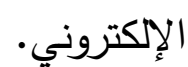

ب- التزام جهة الإصدار بتقديم تقارير إحصائية نقدية بشكل دوري إلى السلطات النقدية: "إن إصدار النقود الإككترونية قد يؤثر في السياسة النقدية من خلال تأثيرها في عرض النقود، وتحسبا لهذا فإنه من الضروري أن تقوم المؤسسات الائتمانية المسموح لها بإصدار النقود الإلكترونية بتقديم بيانات إحصائية دورية إلى السلطات النقدية المتخصصة، كالبنك المركزي مثلا، وذلك من أجل رفع كفاءة السياسة النقدية، ويجب على هذه التقارير أن توضح حجم النقود الإلكترونية التي تم إصدارها، أو المزمع إصدارها، وذلك خلال فترة زمنية محددة". (الشافعي، ( T ع - إلزام جهات إصدار النقود الإكترونية بتحويلها إلى نقود ورقية: فلا شك أن سمعة جهة الإصدار عليها معول كبير
المبحث الثالث: الضوابط الثرعية للنقود الرقمية. إن الضابط الشرعي لما يصح أن يكون نقدا هو "أن يكون محدودا ومنضبطا، لا يرتفع ولا ينخفض، إذ لو كان الثمن يرتفع وينخفض كالسلع لم يكن ثمنا تعتبر به المبيعات، بل الجميع سلع، وحاجة الناس إلى ثمن يعتبرون به المبيعات حاجة ضرورية عامة، وذلك لا يمكن إلا بسعر تعرف به القيمة، وذلك لا لهابه يكون إلا بثمن تقوم به الأشياء ويستمر على حالة واحدة، ولا يقوم هو بغيره، إذ يصير سلعة يرتفع وينخف فتفسد معاملات الناس، ويقع الخلاف".

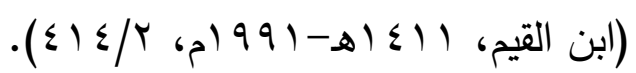
وفيما يتعلق بالنقود الإلكترونية هناك نوعان من الضوابط؛ ضوابط تتعلق بإصدارها، وضوابط تتعلق باستخدامها، وسأذكر كلا من النوعين بشيء من

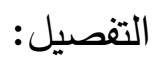
أولا: ضوابط إصدار النقود الإكترونية: ينبغي أن تكون هناك قيود لإصدار العملات الإلكترونية لحماية الأطراف المتعاملة بها من جهة، والحيلولة دون استغلال جهات إصدارها لبقية الأطراف من جهة أخرى، ومن أهم هذه الضوابط ما

1- خضوع جهات إصدارها للإشراف الحكومي والرقابة الدقيقة: فالنقود الإلكترونية يجب أن تتتظم وفق الرؤية الشرعية في شؤون النقود تحت مبدأ مركزيـة الإدارة بدءً من عملية الإصدار، مرورا بالحفاظ على القيمة 
في قبول العملة الإلكترونية والثقة بها وذلك من المتعارف عليها، ويمكن تلخيص هذه الضوابط فيما خلال الوفاء بالتزامها بتحويل النقود الإلكترونية إلى

1- المحافظة على استخدامها وفق الآلية التي تنظمها جهة الإصدار - ت تصن.

r- تجنب إساءة استغلالها في مجالات الإصدار، التهرب

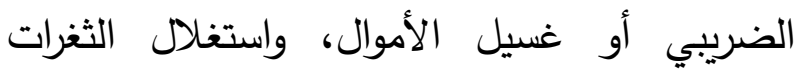
الأمنية للأنظمة الضابطة لها، كأعمال الصرف الضفي المزدوج والسرقة الإلكترونية وغيرها من الجرائم النقدية والإكترونية. ب- مراعاة أحكام الثريعة الإسلامية في المعاملات التي تجري بواسطتها هذه النقود، من بيع وسلم وشركة ونحوها، وكذلك أداء زكاتها وغير ذلك من بن بن الأحكام الثرعية في الأموال.

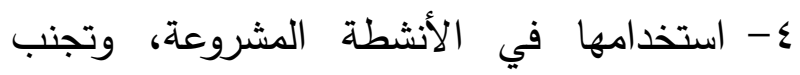
الأنشطة الاقتصادية المحرمة شرعا.

المبحث الرابع: الأحكام الفقهية المتعلقة بعملة الأتئة البتكوين، وفيه مطالب: - البع: المطلب الأول: تعريف عملة البتكوين: التعريف بالبيتكوين: يصف من يسمي البيتكوين

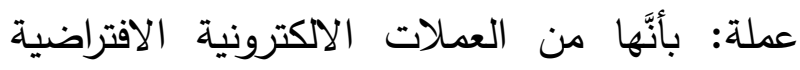
الوهمية التي ليس لها وجود مادي، وهذه العملات على اختلاف أنواعها وتباين طرق الوصول إليها والحصول عليها منتشرة ومعروفة منذ عدة سنوات؛

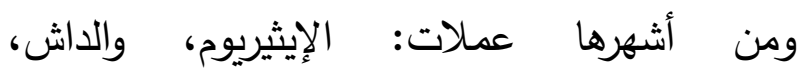
والريبل، واللايت كوين، والإيثيريوم كلاسيك، وهي الإينيرن،

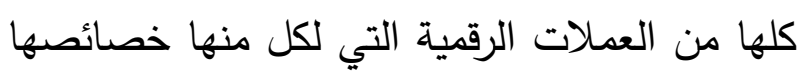

نقود ورقية عند طلب العميل ذلك، مما يؤدي إلى استقرارها النقدي، نتيجة استقرار العلاقة بينها وبين

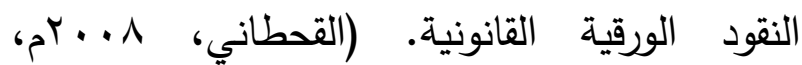
(VT. ، V V ه- إلزام جهات الإصدار بالاحتفاظ باحتياطي نقدي

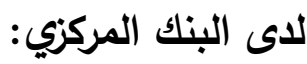
"يتعين على البنك المركزي أن يفرض قيودا خاصة بالاحتياطي النقدي على مصدري النقود الإلكترونية، لئل وذلك تحسبا لأي زيادة كبيرة في خلق النيّي النقود الإلكترونية، مما يؤثر في النهاية على السياسة النقدية، ومن شأن المحافظة على هذا الالتزام أن ئن فئرئ

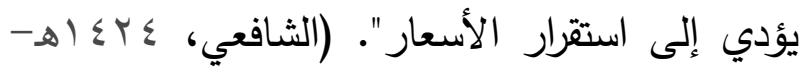

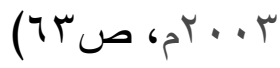
צ- وجود تنسيق وتثريع وتعاون دولي: لأن هذه النقود الإككترونية تتسم بالعالمية وعدم التقيد بالحدود الجغرافية، ومن ثم فإن أية محاولة لممارسة بإنة

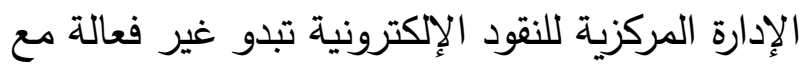

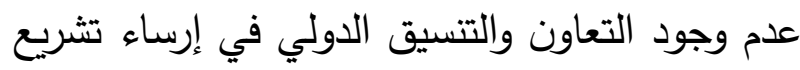

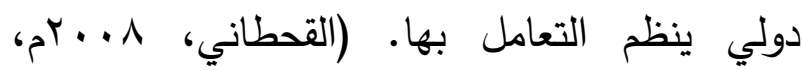
ص د (VT) ثانيا: ضوابط استخدام النقود الرقمية: بما أن النقود الإكترونية تستخدم في المبادلات المالية والنقدية فلابد لها من ضوابط شرعية لاستخدامها، شأنها في ذلك شأن النقود القانونية 


$$
\text { 1- اتساع نطاقها. }
$$

r- السرعة الفائقة في نقل الأموال. r- التحكم وحماية الهوية والأموال. ع - سهولة الاستخدام. 0- انخفاض تكلفة الاستخدام. צ- صعوبة التعقب.

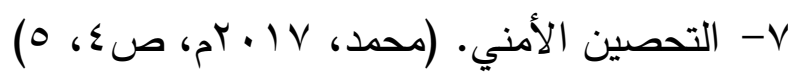
المطلب الثاني: التكييف الفقهي لعملة البتكوين. لنتمكن من تكييف عملة البتكوين لابد من ملاحظة عدة أمور : لتمن من أولا: إنَّ الهدف من اللجوء لمثل هذه العملات يَكْمُن في أنها لامركزية؛ بحيث يمكن أن يتحكم فيها

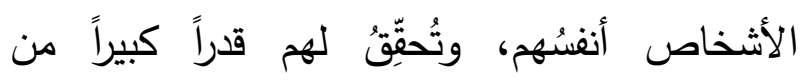

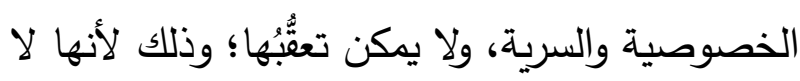
تَعتمد على المؤسسات الرسمية والجهات المالية الوسيطة كالمصارف. ولكونها لا ترتبط بأي مؤسسة

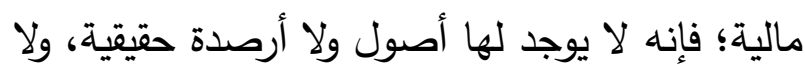
تحميها أية ضوابط أو قوانين مالية، ولا تخضع لانه لسلطة رقابية، وكان هذا أحد أسباب تَعَرُِّهِها لارتفاعات مهولة أو انخفاضات حادة، ويضاف إلى لى لهان ذلك كله: جهالة من يقف وراء ترويج هذه العملة الوهمية؛ مما يجعلها لدى أي تغيرات طارئة: عرضة دهن

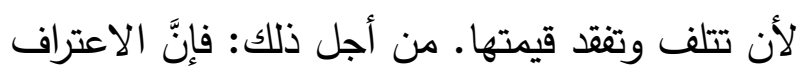
بالبيتكوين كعملة قانونية لم تعتمده أي دولة من دول

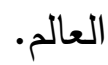
ثانياً: من أهم ما تشترطه الشريعة لاعتبار أي شيء
ومميزاتها وطرق معالجتها وتوليدها. وتعرف البتكوين بأنها عملة إليكترونية يمكن مقارنتها

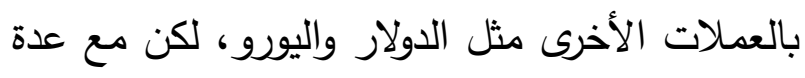

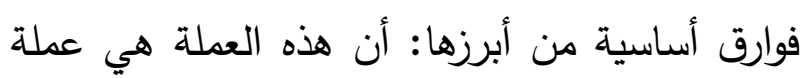
إلكترونية بشكل كامل يتم تداولها عبر الإنترنت فقط انرها

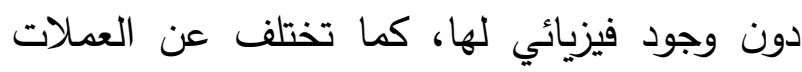

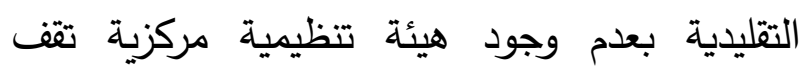
خلفها، لكن يمكن استخدامها كأي عملة أخرى للشراء عبر الإنترنت أو تحويلها إلى عملات تقليدية.

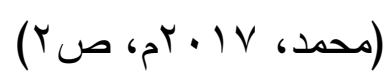

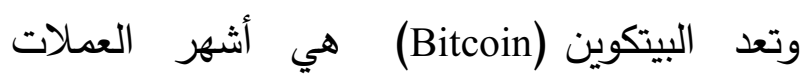
الافتراضية حاليا، وتتكون من عنوان رقمي مربوط بمحظة اليكترونية وكل بتكوين مقسم لمائة مليون

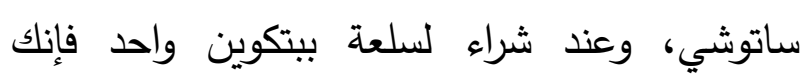
ستحول البتكوين بضغطة زر إلى محفظة البائع

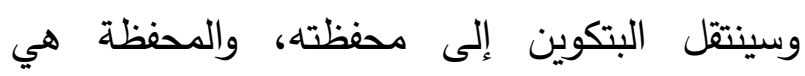
تطبيق إليكتروني، وعندما يريد أي شخص تحويل البكوين قيمة معينة من البتكوين إلى شخص آلى آخر فإنها يستخدم ما يسمى بالتوقيع الرقمي، وهذا التوقيع

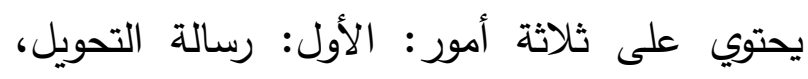

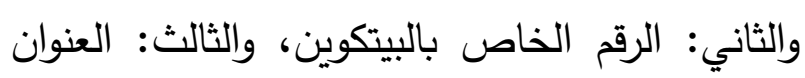
المعلن للشخص الذي سيستلم البيتكوين، وعندما يتم تحويل بتكوين إلى محفظة أخرى، فان التحويل يذهب إلى شبكة البتكوين، ويدخل في عملية التأكد ويتم حفظه في سلسلة البلوكات (Block Chain) • ومن أهم خصائص عملة البتكوين: 
واضحة تمام الوضوح: فكل شيء -حتى الجلود ونحوها- إذا قامت الدولة بسكه عملة، وراج تداولها بين الناس رواج النقود الذهبية والفضية، لاطمئنانهح لحماية الدولة وضمانها لقيمتها؛ فإنها في هذه الحالة تعتبر نوعاً من أنواع النقود، وتأخذ حكم النقد الذهبي أو الفضي الذي يحمل قيمة بذاته، ومن ذلك، أنه لا يجوز صرف بعضه ببعض نسيئة، ولا صرفه نسيئة بأي نوع آخر من أنواع النقود، وبهذا يتضح أن الشرط الأساس شرعا لاعتبار الشيء عملة نقدية، هو : أن تعتمد الدولة ذلك رسمياً؛ لتكون بذلك ضامنة لقيمتها، ولتتوفر لها الحماية القانونية التي تمكنها من القيام بوظيفتها الأساسية، وهي: كونها مقياساً لقيم المقومات، وثمناً للسلع ووسيلة للوفاء بالديون وذلك ليطمئن الناس عند التعامل بها على ضمان حقوقهم، والوفاء بالتزاماتهم. وبناء على ذلك: فإذا بحثنا في البتكوين على اعتبار أنها عملة - لم نجد المعيار المذكور متوفراً فيها. ثالثا: أن الجهالة تحيط بالبتكوين من كل الجهات: فهي تعتمد على مبادئ التشفير في جميع جوانبها، ولا يتضمن قانون التعامل بها أية معلومات عن الشخص أو بياناته؛ فالجهالة ترافقها بدءاً من اكتسابها واستعمالها، وكل ذلك يؤدي إلى الغرر والغش المنهي عنهما إجماعاً في الثريعة الإسلامية؛ والأدلة على ذلك كثيرة منها: قوله تعالى: فَلَّولَلَ

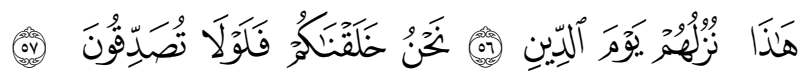

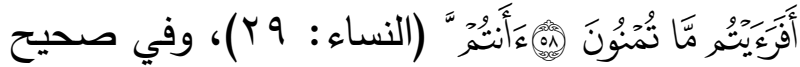

عملة هو: اعتماد الدولة لها، أي: أن تكون صادرة من جهة الدولة، وهو ما يعبر عنه عند الفقهاء بسك النقود، أو ضرب النقود، وبيان ذلك أنَّ اعتماد العملات المالية يعتبر في الشريعة وظيفة خاصة بالدولة، فالدولة وحدها هي التي يحق لها إصدار النقود، وفقاً للقوانين المعتمدة لديها والمنظمة لذلك، وتجد ذلك صريحاً في نصوص الفقهاء، سواء كان بالنسبة للنقود المعدنية - من دنانير ذهبية أو دراهم فضية، مما تحمل قيمة في ذاتها والتي كانت سائدة فيما مضى، وكذلك بالنسبة للعملات الائتمانية التي تعتمد على قوة القانون، وليس لها قيمة في ذاتها: كالعملات الورقية، والتي أصبحت هي السائدة في جميع أنحاء العالم، وفيما يأتي نذكر بعضاً من هذه النصوص، ونبدأ بما يخص العملة التي تحمل قيمتها بذاتها: فعن الإمام أحمد أنه قال: "لا يصلح ضرب الدراهم إلا في دار الضرب، بإذن السلطان؛ لأن الناس إن رُخص لهم ركبوا العظائم". (الفراء،

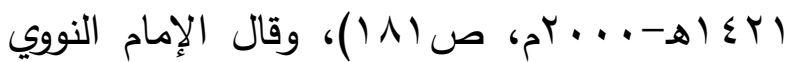
في الروضة: "ويكره للرعية ضرب الدراهم وإن كانت خالصة؛ لأن ضرب الدراهم من شأن الإمام"

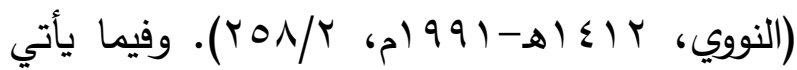
نورد نصاً شاملاً لِنَوعَي العملة، قال الإمام مالك في المدونة: "ولو أن الناس أجازوا بينهم الجلود؛ حتى تكون لها سكة وعين؛ لكرهتها أن تباع بالذهب

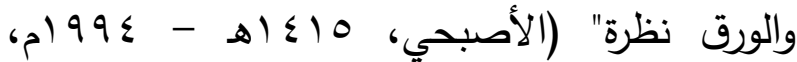
ب/\%) وكلام الإمام مالك هنا قاعدة - في النقود - 
العُلةِّة الورقيَّة، وتُوجَدُ بعضُ الأنواعِ التي يزعُم

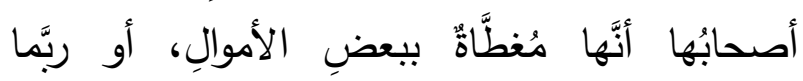

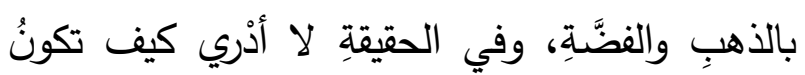

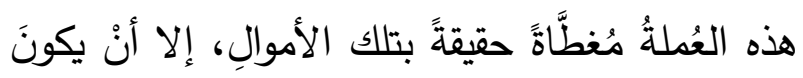

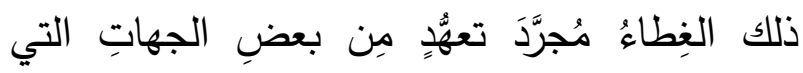

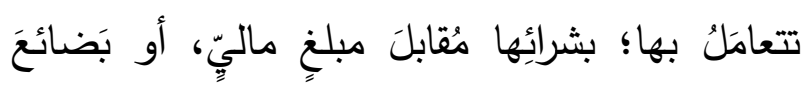

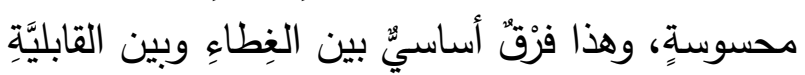
للثِّراءِ.

سادسا: أنَّ العُملةً الورقيَّةَ لا تصدُرُ في الغالبٍ إلا

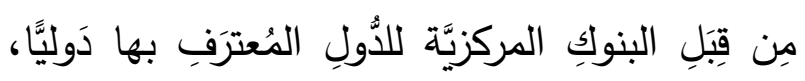

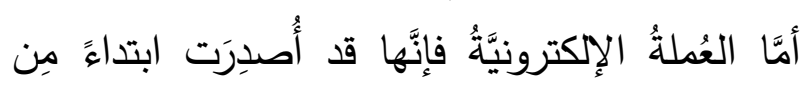

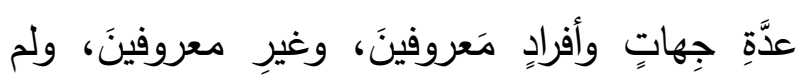

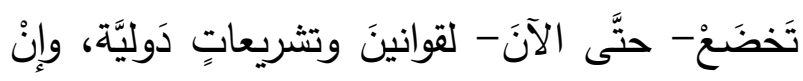

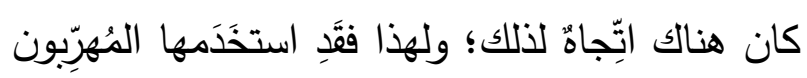

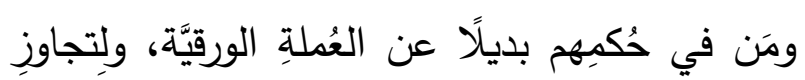

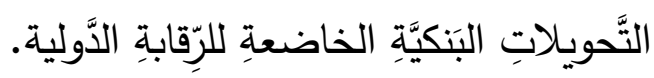

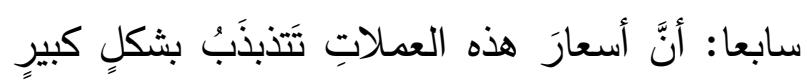

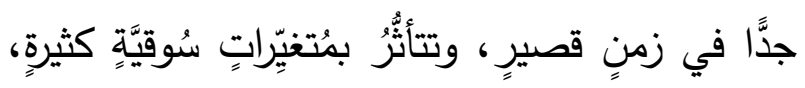

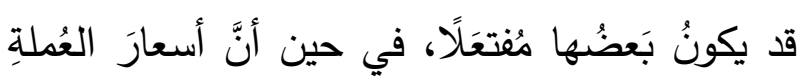

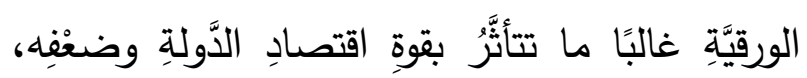

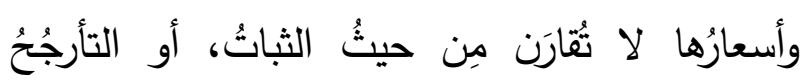

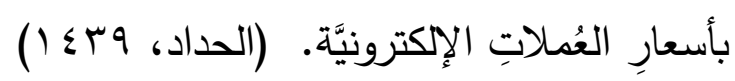
https://dorar.net/article/1982

ثامنا: استخدمت الجماعات الإرهابية البتكوين كوسيلة للحفاظ على بقائها توفر لها موارد مالية ثابتة تصعب ملاحقتها ومصادرتها من قبل السلطات

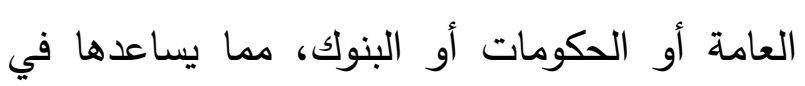

مسلم عن أبي هريرة كرضي الله عنه- قال: نهي

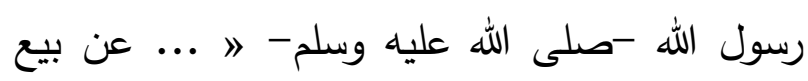
الغرره (مسلم، ح: س اله (1)، وعنه أيضاً أن رسول

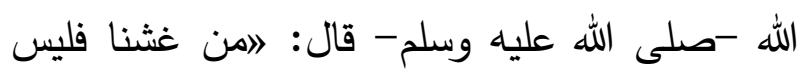
مناه (مسلم، ح: \& 1 (1)، الإجماع: يقول ابن العربي

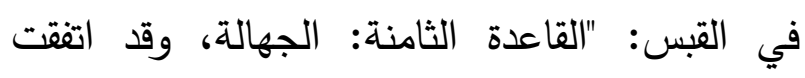

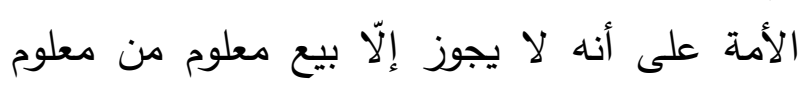
بمعلوم بأي طريق من طرق العلم وقع" (ابن العربي،

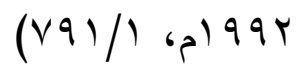

رابعا: خلو المعاملة من الضرر الدحرم. فهل التعامل

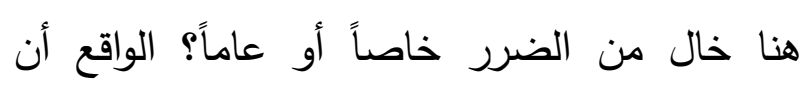
البيتكوين خارج عن رقابة الجهة المسؤولة -سواء اعتبرناها عملة أو سلعة- وهذا يؤدي حتماً إلى الى الى الى إضعاف تحكم الدول في أسواقها المالية والتجارية مما يؤدي إلى حدوث أضرار متوقعة، بل قد يكون الندالية الضرر محققاً في بعض الصور • فهي تُلحق الضرر باقتصاد الدول، وقد تؤثر على استقرار المجتمعات بما تَتَبب فيه من انتثار التجارات الدحظورة، وغسيل الأموال، والتحويلات المالية؛ التي يمكن أن تستخدمها الجماعات المحظورة بتداول هذا النوع من الند العملات، والضرر يزال؛ ففي الحديث الذي أخرجه

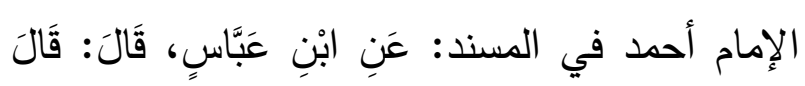

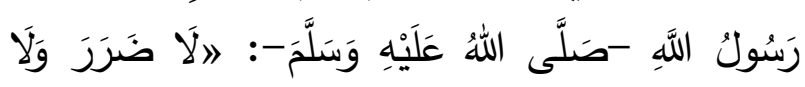

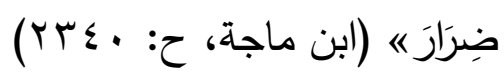
خامسا: أنَّ أغلَب أنواعِ هذه العُملةِ غيرُ مُنطَّى بأيِّ

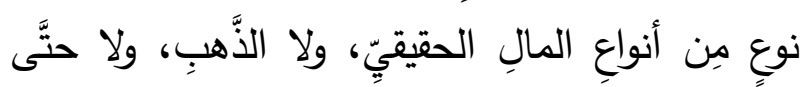


الفضَّة، وتلك الوعودُ المُونَّقَُّ أو سَنداثُ الملكيَّة هي ما عُرِتَ بعدَ ذلك بالأوراقِ النَّدَيَّة.

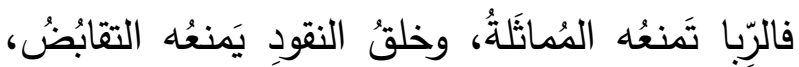

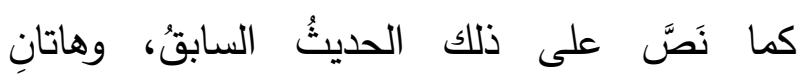

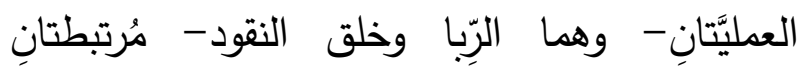

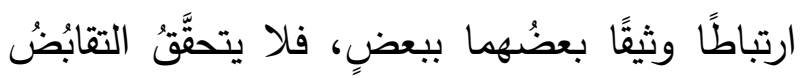

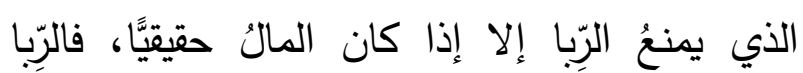

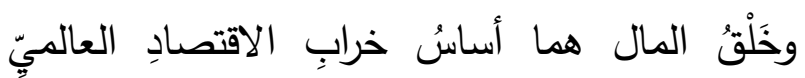

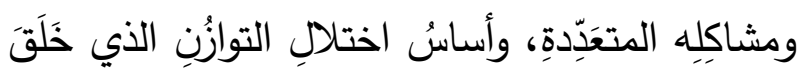

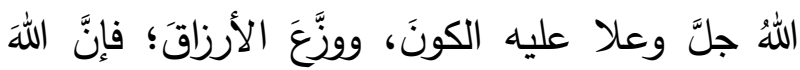

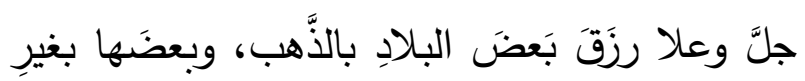

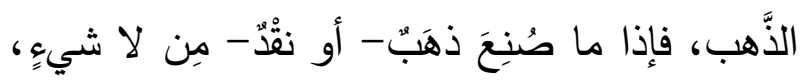

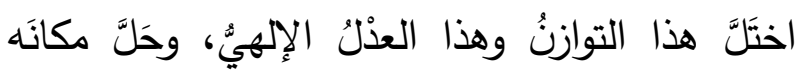

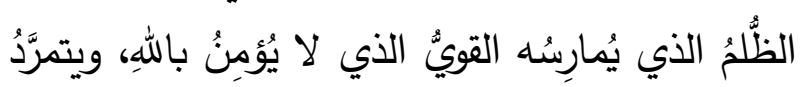

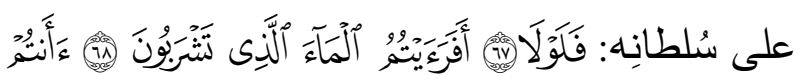

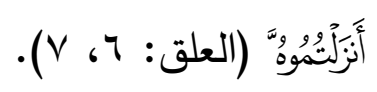

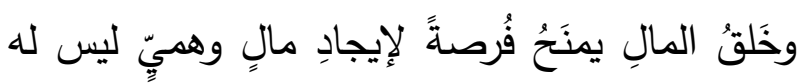

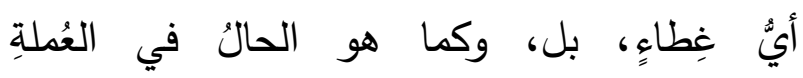

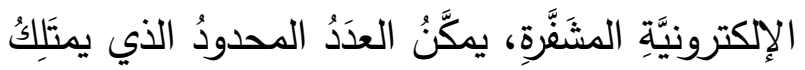
مهاراتِ خَلقِ المالِ مِن الحُصولِ على الثُرَّةوة ورِيَّما

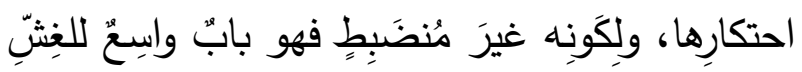

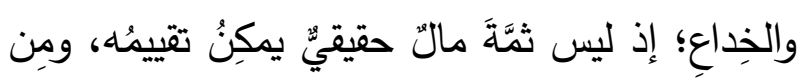

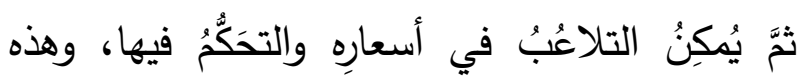

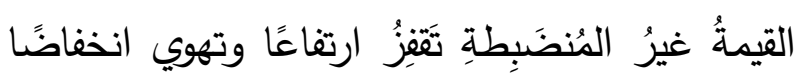

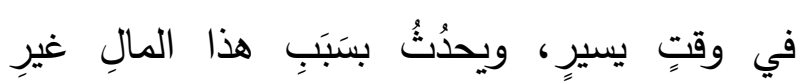

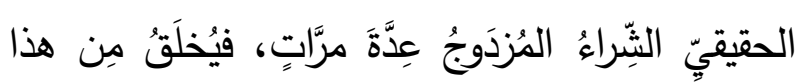

إخفاء مواردها المالية، وتثفير عمليات نقل الأموال

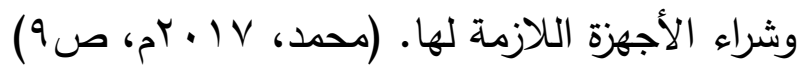
المطلب الثاثث: الحكم الثرعي لعملة البيتكوين.

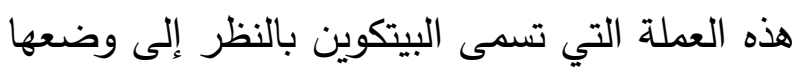
الحالي لا تتوفر فيها المواصفات اللازمة لجعلها لكانيا عملة قابلة للتداول، على نحو ما تتداول به العملات

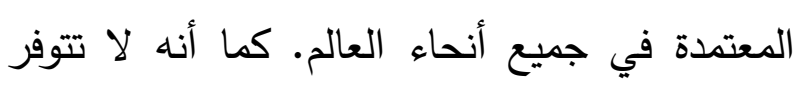

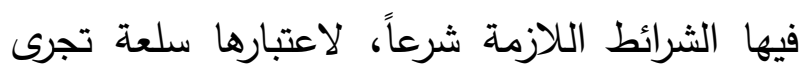
المقايضة بها مع سلع أخرى.

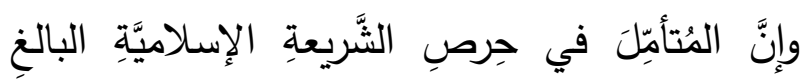

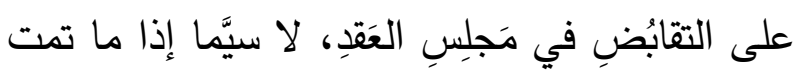

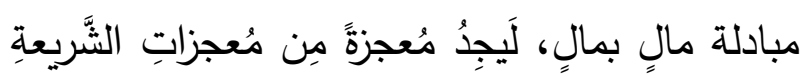

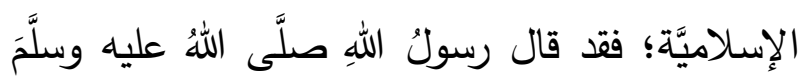

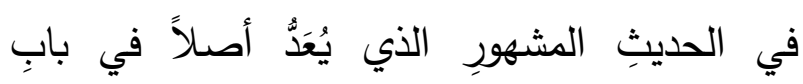

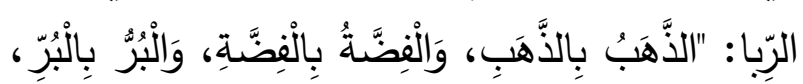

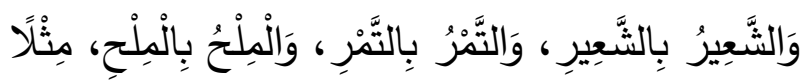

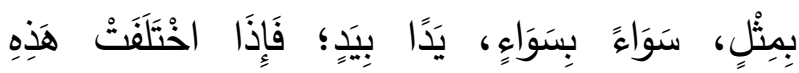

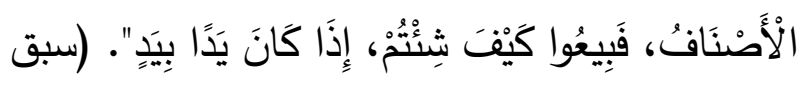
تخريجه).

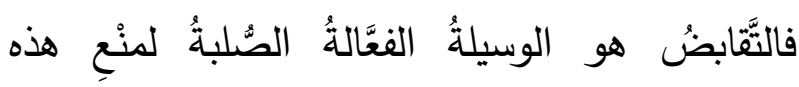

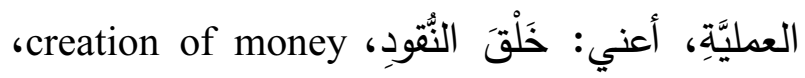

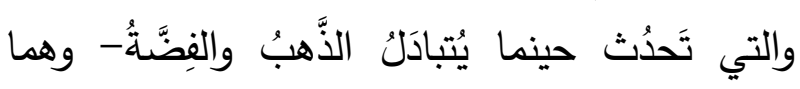

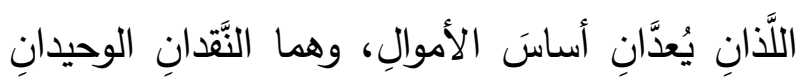

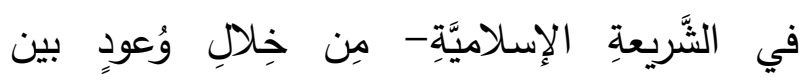

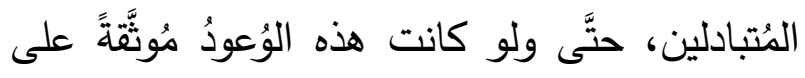

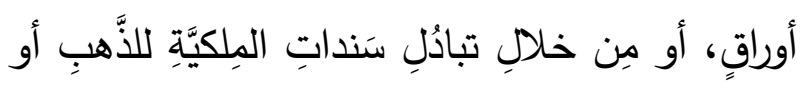




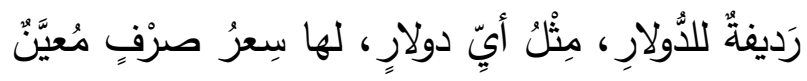

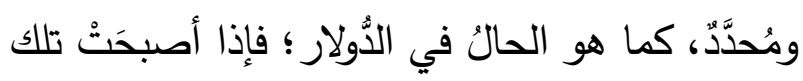

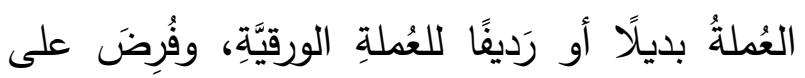

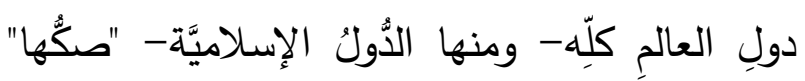
كبَديلٍ أو رَديفٍٍ للعملةِ الورقيَّة، وأمكَنَ ضبنطُ سِعرِها

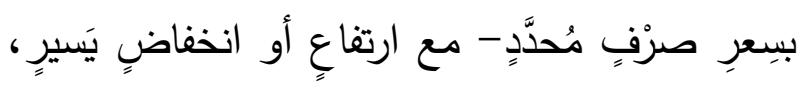

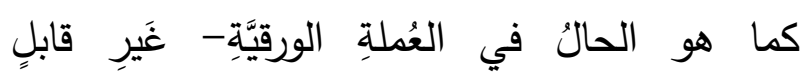

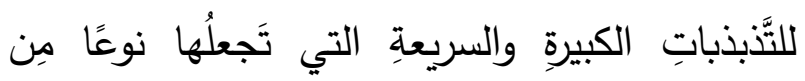

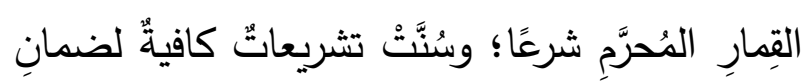

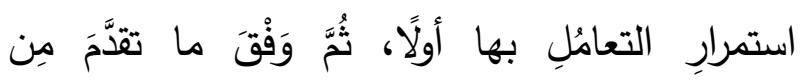

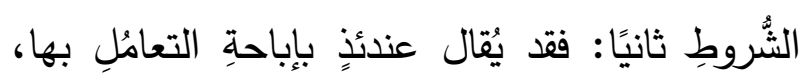

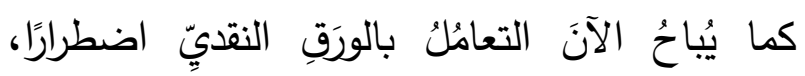

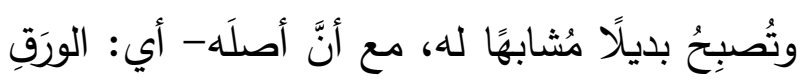

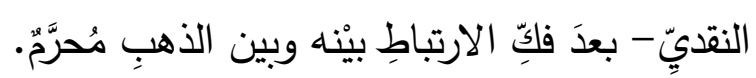

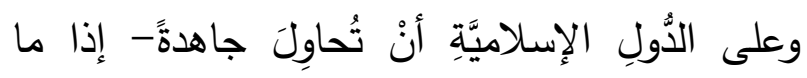

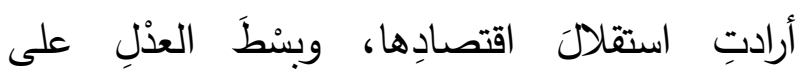

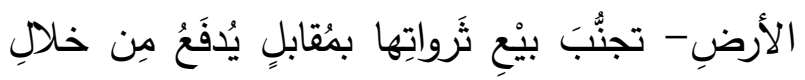

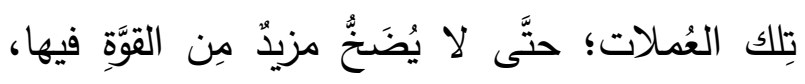

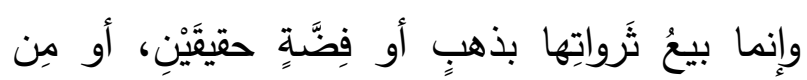
خلالِ مُعايضةِ بأموالٍ منقولةِة. وفيما يلي عرض لأهم الفتاوى الصادرة من العلماء وجهات الفتوى الرسمية المعتدة بشأنها: فتوى الثيخ الدكتور عبدالله المطلق عضو هيئة النياء كبار العلماء بالمملكة: حذَّر عضو هيئة كبار العلماء المستثار في الديوان الملكي، الثيخ الدكتور عبدالله بن محمد المطلق، من الكن الكان

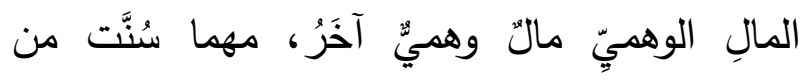

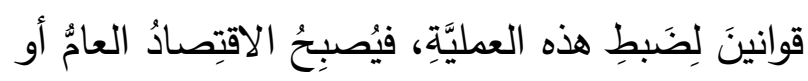

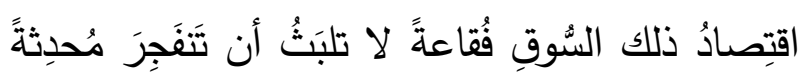
دَمارًا هائلًا.

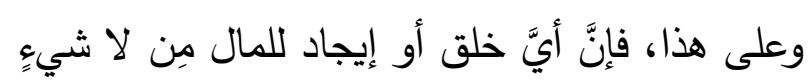

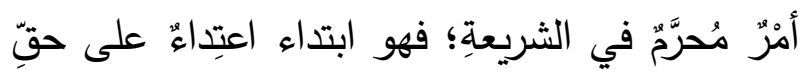

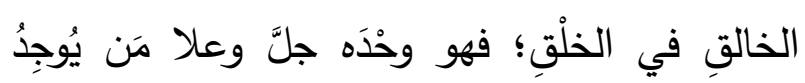

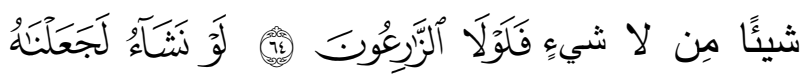

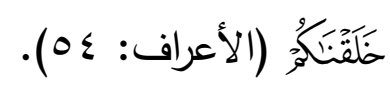

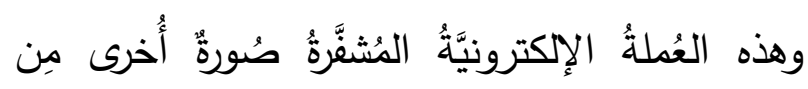

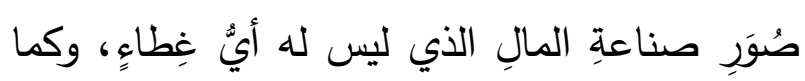

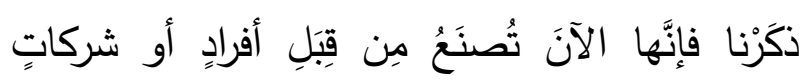

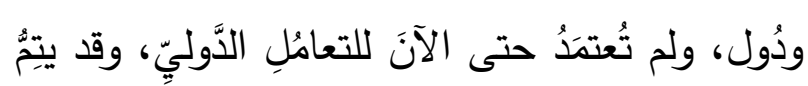

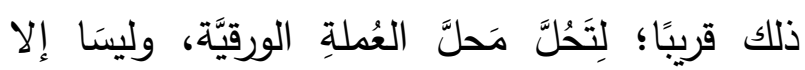

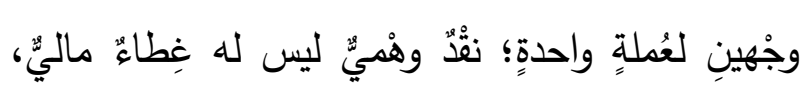

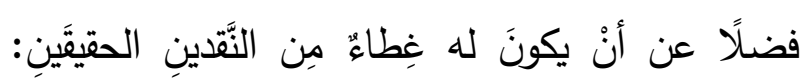

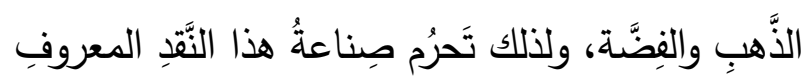

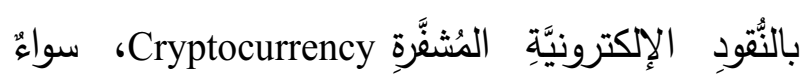

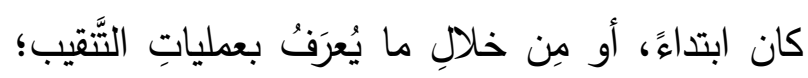

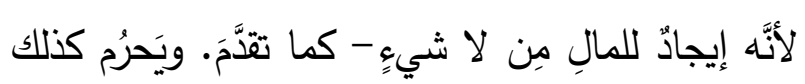

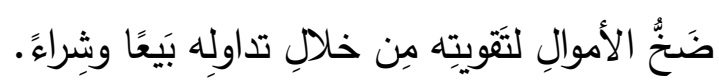

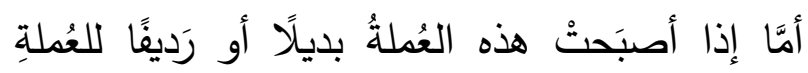

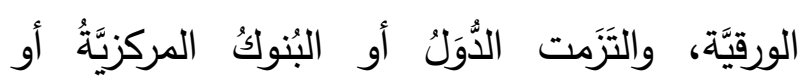

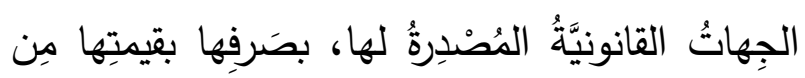

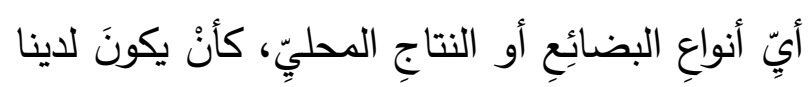

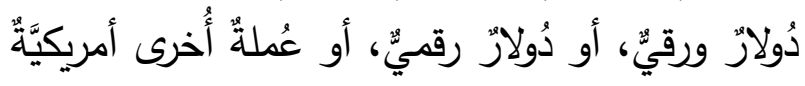


ملاحظات شرعية مهمة، حيث أجاب فضيلة مفتي الديار المصرية الحالي أ.د/شوقي إبراهيم علام

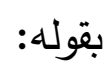
"عملة البتكوين (Bitcoin) من العملات الاقتراضية الأتي طُرِت للتداول في الافراضية (Virtual Currency)

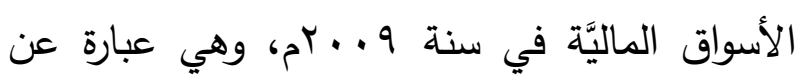

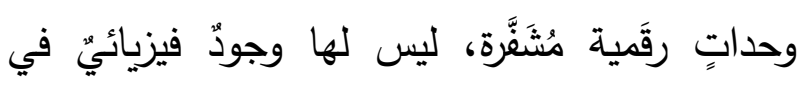
الواقع، ويمكن مقارنتها بالعملات التقليديَّة؛ كالدولار ، أو اليورو مثلًا .. وهذه الوحدات الافتراضية غيرُ

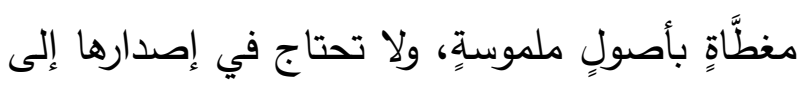

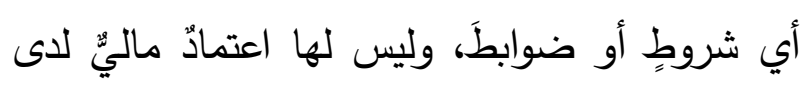
أيّ نظامٍ اقتصادي مركزي، ولا تخضعُ لسلطات

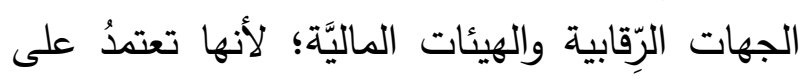

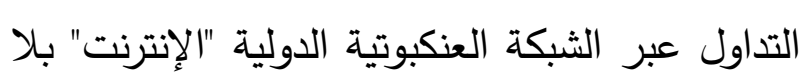
سيطرة ولا رقابة. وفي هذا السياق لم يَفْتُ أمانةً الفتوى بدار الإفتاء

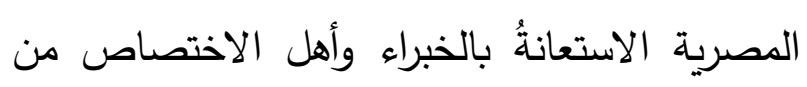

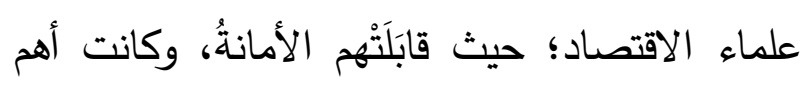
نتائج النقاش معهم:

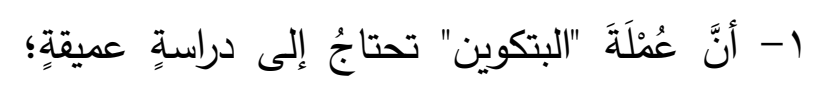

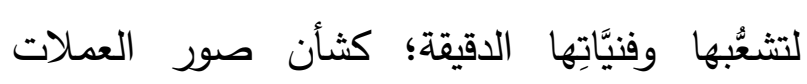
الإككترونية المتاحة في سوق الصرف، إضافةًا إلى كلى

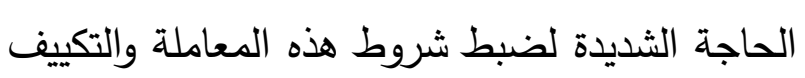

$$
\text { الصَّحيح لها. }
$$

r- أنَّ من أهم سمات سوقِ صرفِ هذه العملات

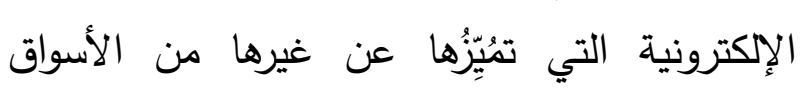

خطورة التعامل بالعملة الرقمية "البتكوين"، وشدد

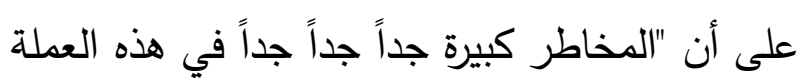

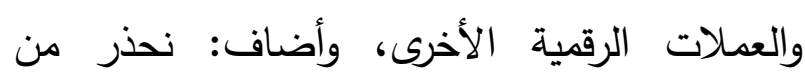
الدخول فيها؛ لأن المال غالٍ، وحرم الثرع إضاعته

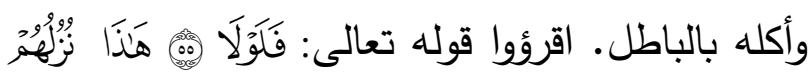

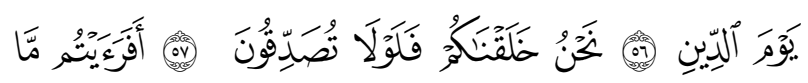

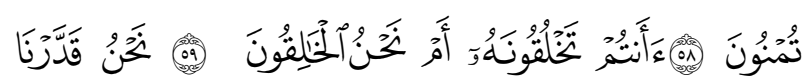

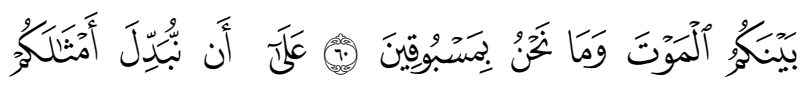

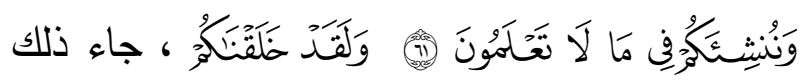
في بيان الثيخ "المطلق" عن حكم التعامل بالعملة الرقمية "البتكوين"، ضمن برنامج فتاوى على التهن التناة السعودية الأولى، وقال: "هذه عملة رقمية ليس لئن وراءها دولة ولا يعرف من أول من أنتجها ولا يعرف لها دولة تحميها، وقد حذرت البنوك المركزية ومنها البنك المركزي السعودي مؤسسة النقد العربي من الندان

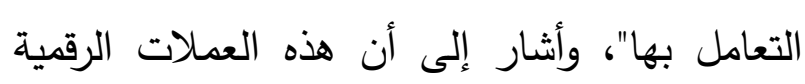

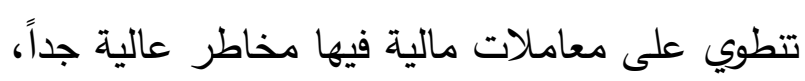
وهي مضاربة عملات، لا يدخل فيها إلا إنسان لا لال

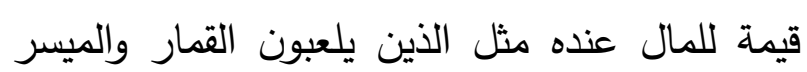
لكن المسلم لا يدخل في الغرر. https://sabq.org/NGZvjV فتوى دار الإفتاء المصرية: وردا على سؤال: ما حكم التعامل بيعا وشراء في التياء العملة الإلكترونية التي تسمى بالبتكوين؟ صدرت عن دار الإفتاء الدصرية فتواها الدسلسلة برقم

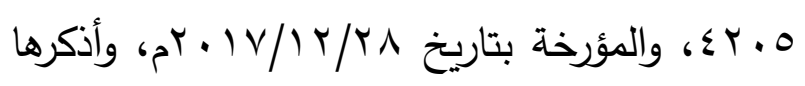

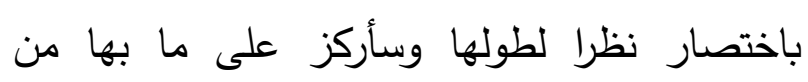


الماليَّة أنها أكثرُ هذه الأسواق مخاطرةً على العمليَّات ولا القائمين بها، وتسهيل بيع الممنوعات الإطلاق؛ حيث ترتفع نسبةُ المخاطرة في المعاملات وغسل الأموال عبر هؤلاء الوسطاء.

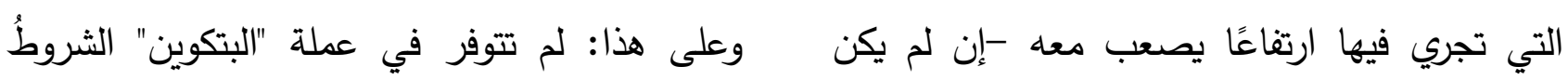

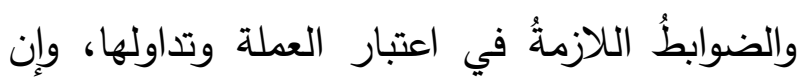
مستحيلًا- التنبؤُ بأسعارها وقيمتها.

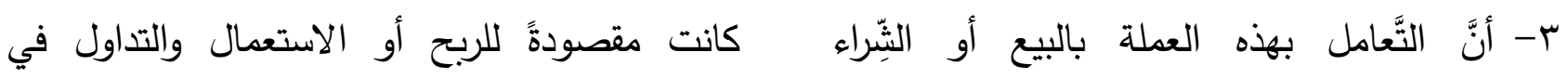
بعض الأحيان، إلا أنها مجهولةٌ غير مرئيةٍ أو الو

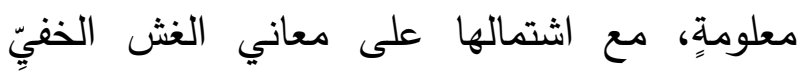

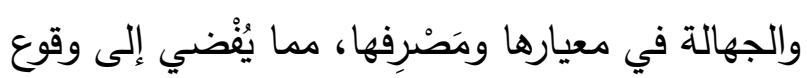
التلبيس والتغرير في حقيقتها بين المتعاملين؛ فأشبهت بذلك النقودَ المغشوشة ونفاية بيت المال، وبيع تراب الصَّاغة وتراب المعدن، وغير ذلك من لنّان

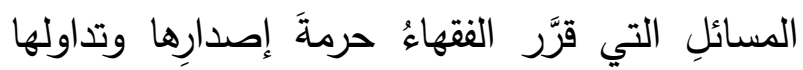
والإبقاء عليها وكنزها؛ لعدم شيوع معرفتها قدرًا ومعيارًا ومَصْرفًا؛ ولما تشتمل عليه من الجهاء لجهالة والغش، وذلك يدخلُ في عموم ما أخرجه الإمام مسلم

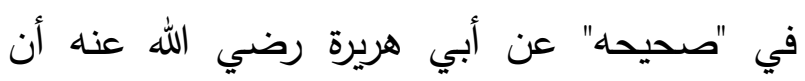
رسول الله صلى الله عليه وسلم قال: "مَنْ غَشَّنَا فَلَيَّنَ

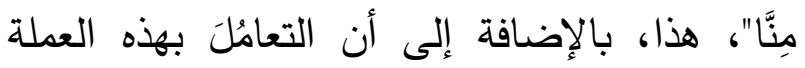

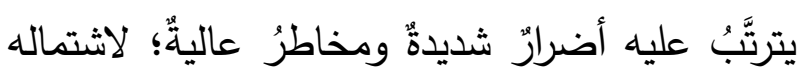
على الغرر والضَّرر في أشدِّ صورهما. وقد اتفق الاقتصاديون وخبراء المال على أن هذه ولهن

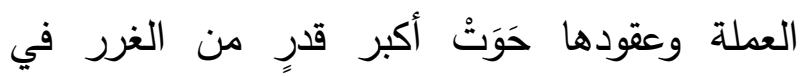

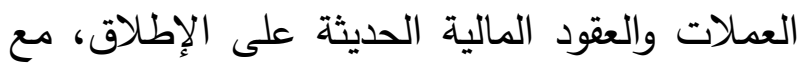

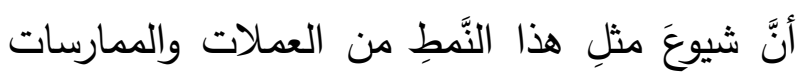

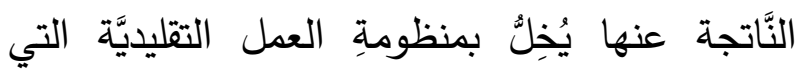
تعتمدُ على الوسائطِ المتعددة في نقل بلَّل الأموال وحيازتها يحتاجُ إلى تشفيرٍ عالي الحماية، مع ضرورة عمل نسخٍ احتياطيَّة منها من أجل صيانتها من عمليات القَرصنة والهجمات الإلكترونية لفَكَِّ - التَّفير ـ- أنَّهَه لا يُوصَى بها كاستثمارٍ آمنٍ؛ لكونها من

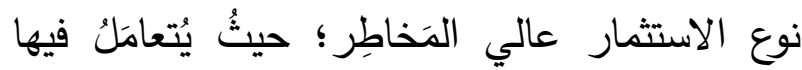
على أساس المضاربة التي تهُف لتحقيق أرباحِ غير

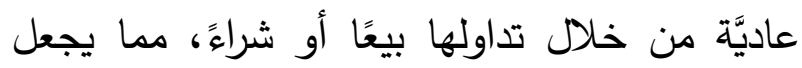

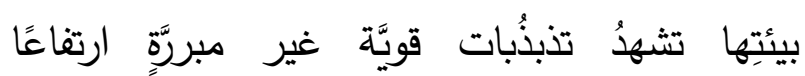
وانخفاضًا.

0- أنَّ مسؤوليَّة الخطأ يتحملها الثخص نفسه تجاه

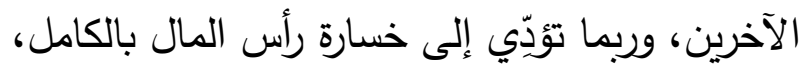
بل لا يمكن استرداد شيءٍ من المبالغ المفقودة جرَّاء ذلك غالبًا، بخلاف الأعراف والتقاليد البنكية المتَّعة في حماية المتعامل بوسائلِ الدفع الإكتروني التي لي لئي تجعل البنوك -عند الخلاف مع المستثر - حريصةً

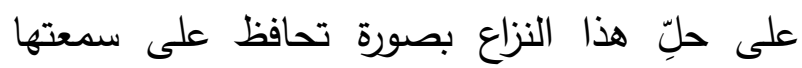
البنكيَّة.

7- أنَّ لها أثثرًا سلبيَّا كبيرًا على الحماية القانونية

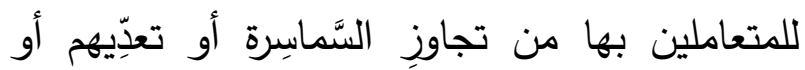
تقصيرِهم في ممارسات الإفصاح عن تفاصيلِ تلك 
مهنيًا جسيمًا ترتب عليه خسارةً العيل. بالإضافة إلى تعدي تأثير التعامل بها اقتصاديًا حيز التأثير على مدخرات الأفراد المتعاملين بهذه العملة إلى اقتصاديات الدول؛ حيث تقف الدولُ عاجزةً أمام الأضرارِ التي تقعُ على عملاتها من جرَّاء هذه التهات الخسائر ، بل يؤدي النظام الذي يُنَظِّمِ ممارسات استخدام هذه العملة حاليًا إلى اتخاذها وسيلةً سهلةً لضمان موارد مالية مستقرة وآهنة للجماعات الإرهابية والإجرامية، وتيسير تمويل الممارسات المحظورة وإتمام التجارات والصفقات المنوعة: كبيع السلاح والمخدرات، واستغلال المنحرفين للإضرار

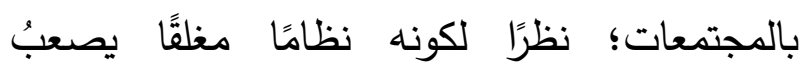
خضوعُه للإشراف وعمليات المراقبة التي تخضع لهات التهات سائر التحويلات الأخرى من خلال البنوك العادية في العملات المعتمدة لاى الدول، والقاعدة الثرعية

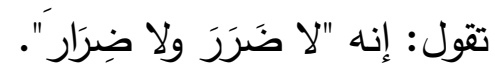

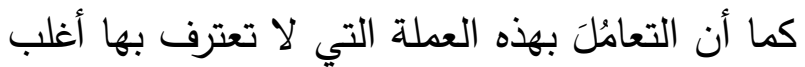
الدول، ولا تخضع لرقابة المؤسسات الدصرفية بها لئان والتي على رأسها البنوك المركزية الدنوط بها تنظيم السياسة النقدية للدول وبيان ما يقبل التداول من النقود من عدمه -ججعل القائم به مفتئًا على ولي للئ الأمر الذي جَعل له الشرعُ الثريفُ جملةً من لهن الاختصاصات والصلاحيات والتدابير ليستطيع أن يقومَ بما أُنيط به من المهام الخطيرة والمسؤوليات الجسيمة. وجَلَ كَكلك تطاولَ غيرِه إلى سَلْبِه شينًا من هذه الاختصاصات والصلاحيات أو مزاحمته
والتَّعامل فيها؛ كالبنوك، وهو في ذاتِ الوقت لا يُنْيَيُُ عملة أو منظومة أخرى بديلة منضبطة

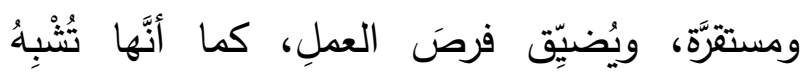
المقامَرَة.

ولِمَا تحويه من المخاطرة الكبيرة التي تشتمل عليها هذه العملة في أصلها؛ حيث إنها تعدُ أثدَّ العملات في الأسواق المالية خطورةً، فإن المقبلين على شراء الفاء

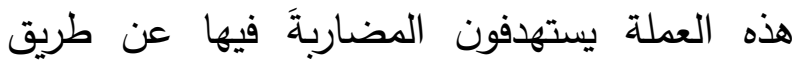

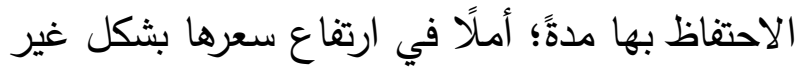

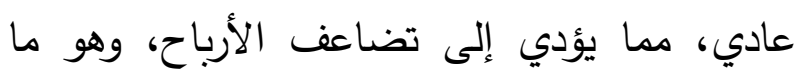
يكذبه تتبع أخبار ومعلومات سوق هذه العملة؛ حيث تكررت سرقة الملايين من هذه العملة، ومن ثََّّ أََّى مباشرة لانخفاض سعرها بشكل كبير، ولا يمكن تحمل مثل هذه الخسارة من قِبل أي بناك أو مؤسسة

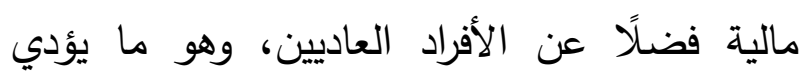
لاستنزاف ثروات الناس وأموالهم وضياعها في شيء العيء

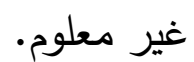
وأما اشتمال هذه العملة والممارسات الناتجة عنها على الضرر، فيتمثل في جهالة أعيان المتعاملين بها وهوياتهم، وإذعان العميل بتحمله الكامل لنتائج هذه المعاملة شديدة المخاطرة مع جهالة أغلب العملاء

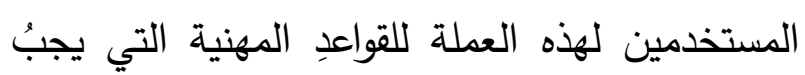

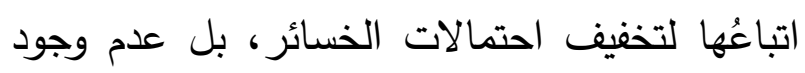
قواعد مهنية أو حماية قانونية كافية يمكن التحاكُ إليها، بما يعني عدمَ قدرة العميلٍ على مقاضاةِ السمسار إذا خالف أوامر العميل أو ارتكب خطي لطياً 
الأمر الممنوع والمحرم؛ لأنها تََدٍِّ على حقه بمزاحمته

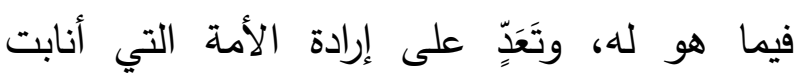
حاكَها عنها في تدبير شؤونها.. وبناءً على ذلك: فلا يجوز شرعًا تداول عملة "البتكوين" والتعامل من خلالها بالبيعِ والثراءِ والإجارِ وغيرها، بل يُمنع من الاشتراكِ فيها؛ لعدمِ اعتبارِها كوسيطٍٍ مقبولٍ للتبادلِ من الجهاتِ المخُتصَّةِ، ولِمَّا تشتمل عليه من الضررِ الناشئ عن الغرِِ والجهالِِ

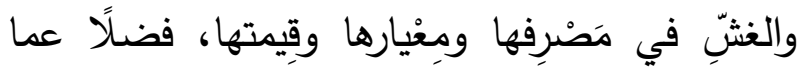

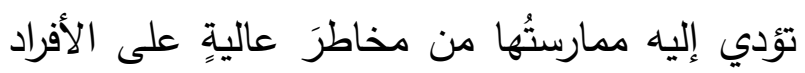
والدول، والله سبحانه وتعالى أعلم." (موقع دار الفتاوى المصرية - الفتاوى - تداول عملة البتكوين والتعامل بها). (http://www.daralifta.org/ar/ViewFatwa.aspx?

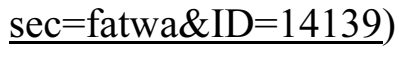

ومما سبق يتضح: أنَّ البتكوين لا تتوفر فيها

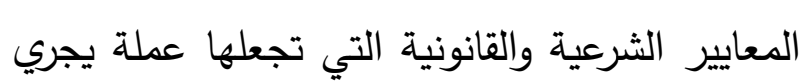
عليها حكم التعامل بالعملات القانونية الرسمية

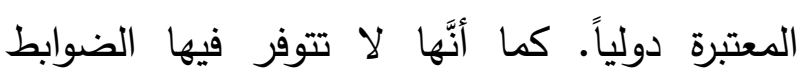

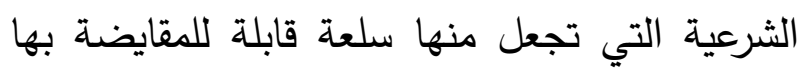

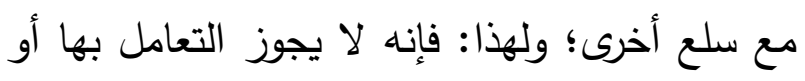

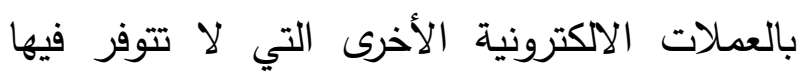
المعايير المعتبرة شرعاً وقانوناً؛ وذلك لأنَّ التعامل لألونل بها يؤدي إلى عواقب غير سليمة: سواء على لمعنى

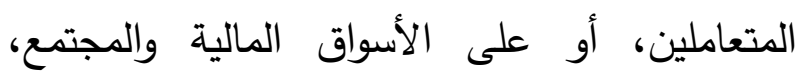

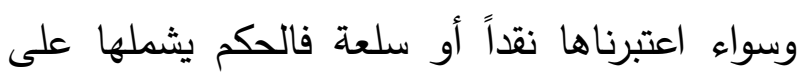

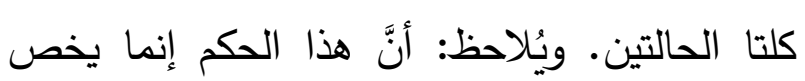

فيها من جملة المحظورات الثرعية التي يجبُ أن

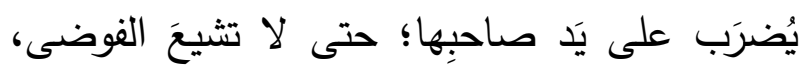

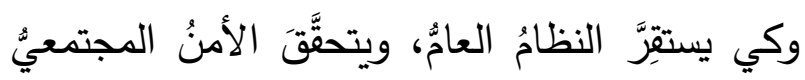

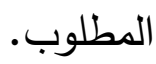
وقد وصف علماء المسلمين من يُنازع ولي الأمر

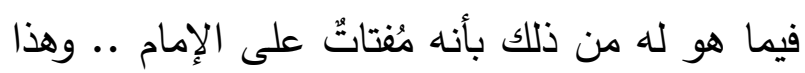

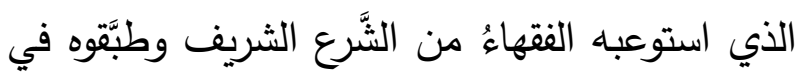
فتاويهم وأحكامهم هو عينُ ما انتهى إليه التتظيمُ لفئر القانوني والاقتصادي للدول الحديثة؛ حيث عمدت القات القوانين إلى إعطاء سلطة إصدار النقد وبيان ما يقبل منه في التداول والتعامل بين مواطنيها ورعاياها تحت اختصاصات البنوك المركزية وتصرفاتها، وفق ونق

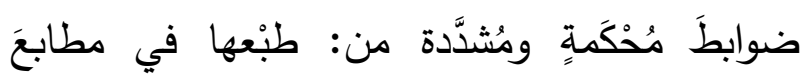

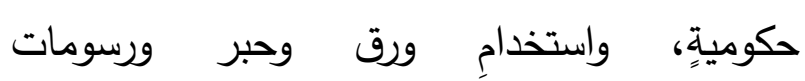

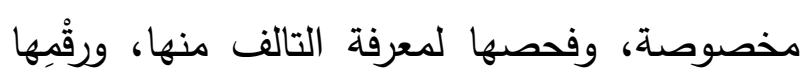

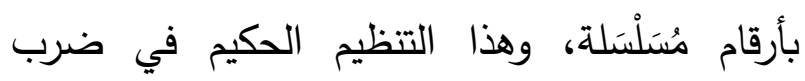

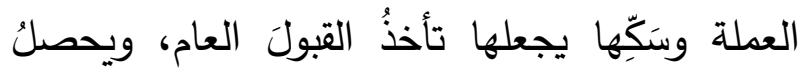
التعارف عليها كوسيط للنقد والتبادل بين الناس حسب العرف الغالب، وهو ضابط قرَّره فقهاء الإسلام في اعتبار العملة المقبولة. واستعمال هذه العملة في التداول يمسُ من سلطة الإنة

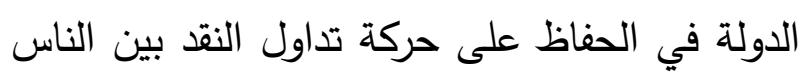
وضبط كمية المعروض منه، وينقص من إجراءاتها الرقابية اللازمة على الأنشطة الاقتصادية الداخلية

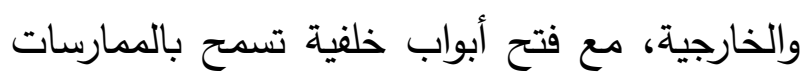
المالية الممنوعة، وذلك كلُه من الافتيات على ولي الثي 
هذه العملات في هذه الفترة، والتي ما زالت خارج توازي النقود الرقمية.

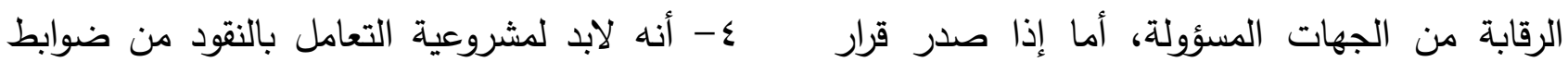

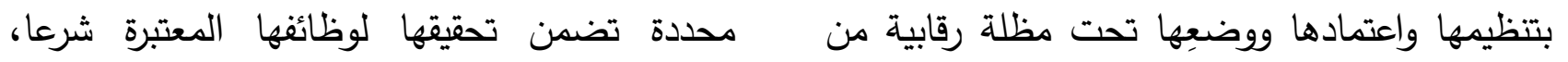

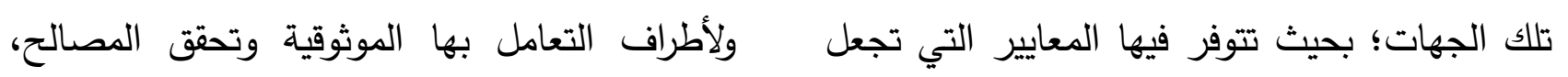
منها عملة قانونية، يجري التعامل بها بين الدول؛ وترفع الغرر والجهالة.

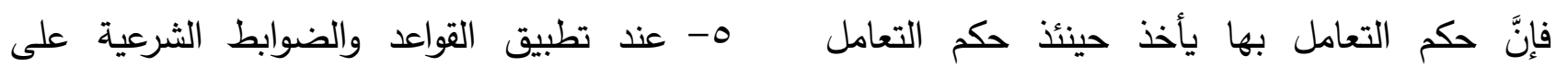
عملة البتكوين وهي من أشهر هذه العملات الرقمية

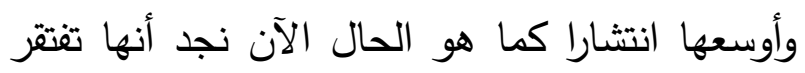

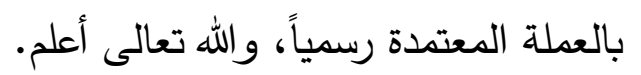
الخاتمة ولنا،

إلى كثير منها مما يترتب عليه القول بحرمتها وهو ما ذهب إليه أكثر العلماء في المملكة العربية السعودية وخارجها من البلدان الإسلامية.

\section{التوصيات}

يوصي الباحث من خلال هذا البحث بعدة أمور :

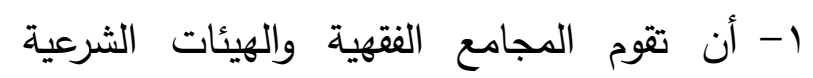
بالدعوة إلى عقد مجمع فقهي مكون من العلماء

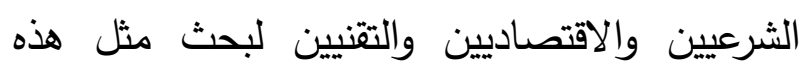
الظاهرة التي أخذت في الانتشار وأقبل عليها كثير

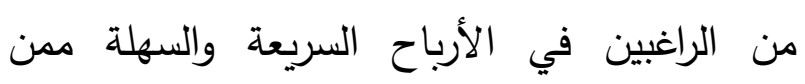
ينخدعون بالإعلانات التي باتت تنتشر على شبكة العنكبوتية وفي المواقع المختلفة. r- أن تقوم الدول والمنظمات المالية والبنوك وفي المركزية بوضع التشريعات المناسبة للتعامل مع هذه العملات الرقمية وتتظيم تداولها. ب- أن تقوم المؤسسات التشريعية والقضائية في

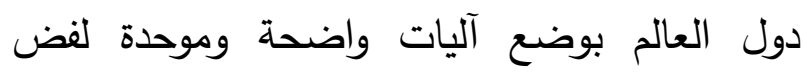
المنازعات التي تتشأ عن التعامل بهذه المعاملات 
وآخرين، الأولى، بيروت: دار الرسالة العالمية.

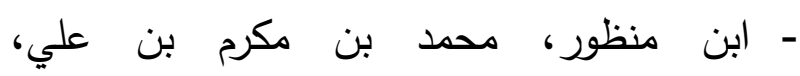

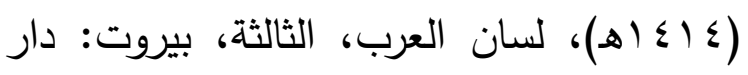

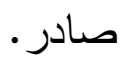

- أبو يعلي، محمد بن الحسين بن محمد الفراء،

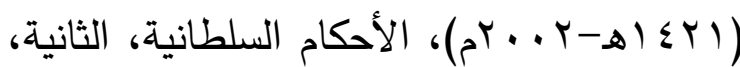

$$
\text { بيروت: دار الكتب العلمية. }
$$

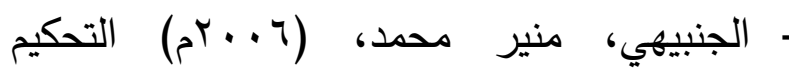
الإلكتروني، الإسكندرية: دار الفكر الجامعي.

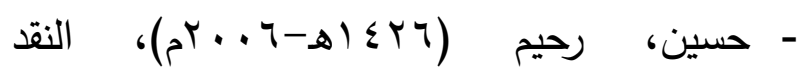
والسياسة النقدية في إطار الفكرين الإسلامي والغربي، الأولى، عَمَّان: دار المناهج للنشر والتوزيع. - الخرشي، محمد بن عبدالله، (د. ت ت)، شرح مختصر خليل، بيروت: دار الفكر.

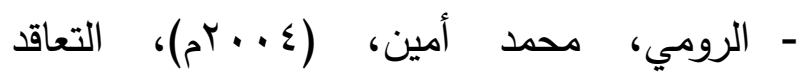
الإلكتروني عبر الإنترنت، الإسكندرية: دار الهين،

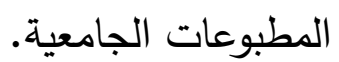

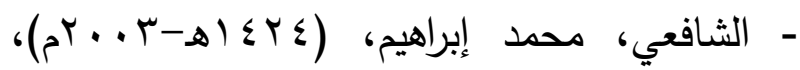
الآثار النقدية والاقتصادية والمالية للنقود الإلكترونية، القاهرة: دار النهضة العربية. - الصنعاني، عبد الرزاق بن همام، (ب (ــ الهـ)،

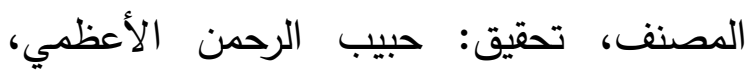
الثانية، الهند: المجلس العلمي.

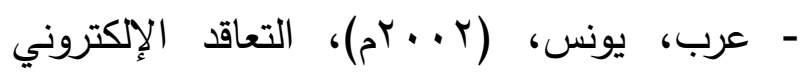
وتحديات النظامين الضريبي والجمركي، جزء من

$$
\text { ورفض الضرر عن المتضررين. }
$$

ع- أن تقوم الأجهزة الأمنية بمتابعة المتعاملين بهذه

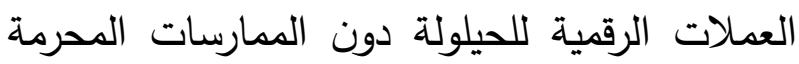
دوليا كغسيل الأموال والنصب والاحتيال وتمويل الجماعات الإرهابية وغيرها من الجرائم المالية والإكترونية التي تتم من خلال التعامل بهذه

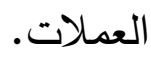

0- استصدار قوانين دولية موحدة لضبط التعاملات

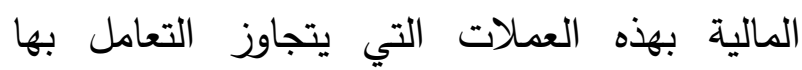
الحدود الدولية والإقليمية.

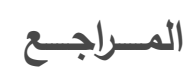

- الأصبحي، مالك بن أنس، (10 (الهـ-199 (م)، المدونة، الأولى، بيروت: دار الكتب العلمية.

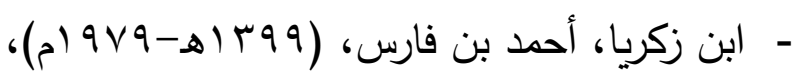
معجم مقاييس اللغة، بيروت: دار الفكر.

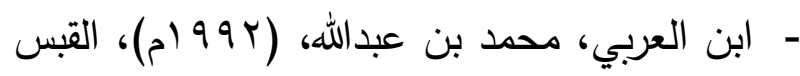

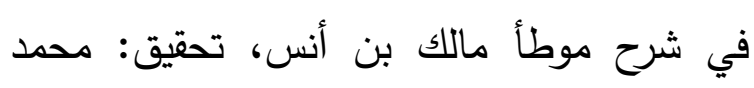

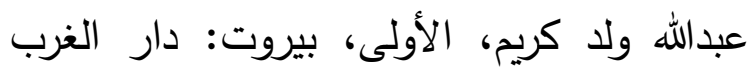

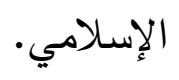

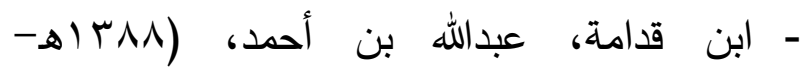

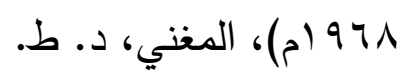

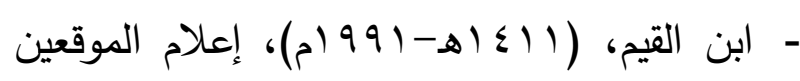
عن رب العالمين، تحقيق: محمد عبدالسلام إبراهيم، الأولى، بيروت: دار الكتب العلمية.

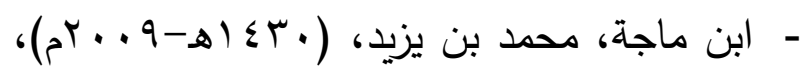
سنن ابن ماجة، تحقيق: شعيب الأرناؤوط 
تمويل الحركات الإرهابية، مركز الملك فيصل للبحوث والدراسات الإسلامية.

- مسلم، مسلم بن الحجاج، المسند الصحيح المختصر بنقل العدل عن العدل إلى رسول الله صلى الله عليه وسلم، بيروت: دار إحياء التراث

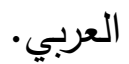

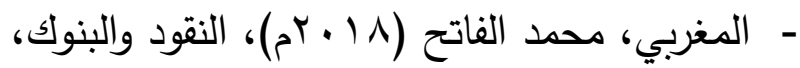

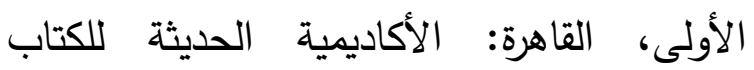
الجامعي. - المقريزي، أحمد بن علي، (9 إماءه)، رسائل المقريزي، الأولى، القاهرة: دار الحديث. - منصور، شيماء جودت مجدي عيادة،

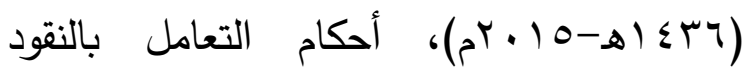
الإلكترونية وأثره على المعاملات المعاصرة، رسالة ماجستير غير منشورة، كلية الثريعة والقانون، الجامعة الإسلامية - غزة.

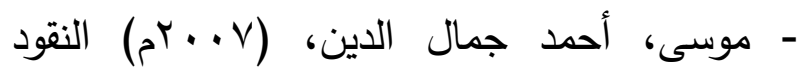
الإلكترونية وتأثيرها على دور المصارف المركزية في إدارة السياسة النقدية، بحث مقدم إلى مؤتمر : الجديد في أعمال المصارف من الوجهتين القانونية والاقتصادية، كلية الحقوق - جامعة بيروت العربية، بيروت: منشورات الحلبي.

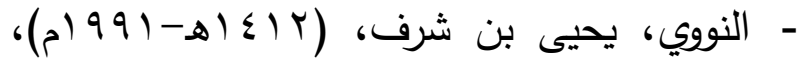
روضة الطالبين وعمدة المفتين، الثالثة، بيروت:

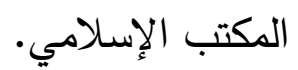

- الوادي، محمود حسين وآخرون، (ابس؟ الهـئ
أوراق عمل برنامج الندوات المتخصصة حول التجارة الإلكترونية، معهد التدريب والإصلاح

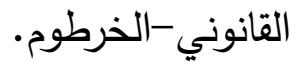
- العقيل، عبدالله محمد عبدالوهاب، (د.ت)، الأل الأحكام الفقهية المتعلقة بالعملات الإكترونية (Bitcoin)، الجامعة الإسلامية بالمدينة المنورة.

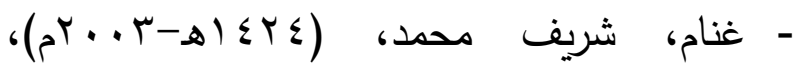
محفظة النقود الإكترونية - رؤية مستقبلية-،

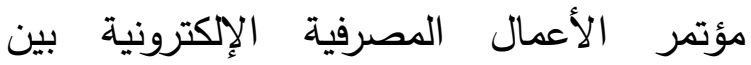
الثريعة والقانون وغرفة تجارة وصناعة دبي، الاعمان الإمارات العربية المتحدة.

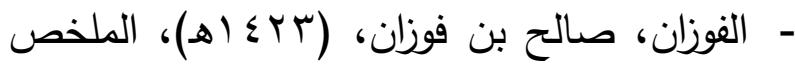
الفقهي، الأولى، الرياض، دار العاصمة.

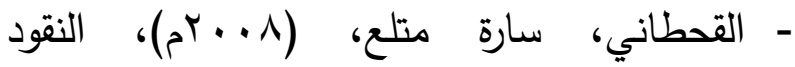
الإلكترونية، حكمها الثرعي وآثارها الاقتصادية، رسالة دكتوراه، كلية الدراسات العليا- جامعة

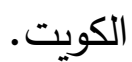
- قلعجي، محمد رواس، وقنيبي، حامد صادق،

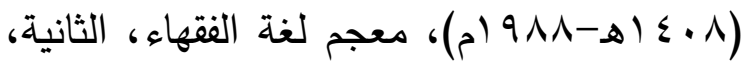
عمّان: دار النفائس للطباعة والنشر والتوزيع.

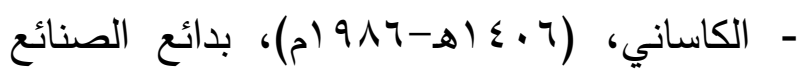
في ترتيب الشرائع، الثانية، بيروت: دار الكتب

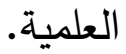
- مجمع اللغة العربية بالقاهرة، (د. ت)، المعجم الوسيط، الإسكندرية: دار الدعوة.

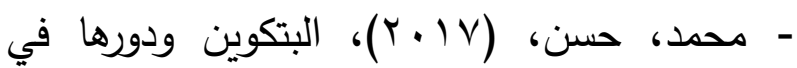


- dorar.net/article/1982

- http://www.dar-

• • • rم)، النقود والمصارف، الأولى، عمان: دار alifta.org/ar/ViewFatwa.aspx?sec=fatwa\&I $\underline{D=1413}$. 


\title{
Associate Professor of Comparative Jurisprudence, Taif University, Department of Sharia, Faculty of Sharia and Law
}

\author{
Yousof Ben Hazzaa Mesaaed Alshereef \\ Abstract . One of the jurisprudential tendencies, and contemporary issues in the transactions of people \\ with the technical progress that has invaded all areas of human life recently known in digital currencies, \\ because of the digital boom and the amazing development that has reached and became threatening paper \\ currencies because they do not need to carry quantities of these papers, It is universal, it eliminates the \\ need to exchange currencies when traveling between different countries. \\ One of the most famous and most prominent of these digital currencies is what is known as the \\ developed, a digital currency that has become famous and spread widely in different parts of the world, \\ and because these currencies now spread and impact on the global economy positively and negatively, \\ and to protect them from circumstances that were not entrusted to people before, To a legitimate view, \\ and a comprehensive study of jurisprudence for all its conditions, implications and effects, so I chose to \\ be the subject of my research is the jurisprudential rules and controls related to digital electronic money \\ (formative model). \\ Research problem: \\ The problem of research is the extent to which e-money transactions are compatible with the Islamic \\ standards and values that are determined by the Shari'a rules regulating transactions. \\ research goals: \\ The research aims to: \\ 1 - Identification of digital currencies and ways to deal with them. \\ 2 - knowledge of the legitimacy of these currencies. \\ 3 - knowledge of the controls of legitimacy to deal with these currencies.
}

